Elżbieta KURZEPA

Politechnika Rzeszowska ${ }^{1}$

Wydzial Zarządzania

Katedra Prawa i Administracji

e_kurzepa@prz.edu.pl

ORCID 0000-0003-0032-8607

https://doi.org/10.34739/dsd.2019.02.08

\title{
ZARZĄDZANIE BEZPIECZEŃSTWEM \\ MNIEJSZOŚCI NARODOWYCH I ETNICZNYCH \\ W POLSCE - OCENA EFEKTYWNOŚCI
}

\begin{abstract}
ABSTRAKT: Problematyka mniejszości narodowych i etnicznych to jeden z elementów polityki bezpieczeństwa państwa, jak również determinanta bezpieczeństwa $\mathrm{w}$ skali międzynarodowej. To kwestia szczególnie istotna obecnie, w czasach wzmożonych ruchów migracyjnych na kontynencie europejskim. Celem niniejszej publikacji będzie przedstawienie założeń systemu zarządzania bezpieczeństwem mniejszości narodowych i etnicznych w Polsce, określenie jego ram prawnych oraz instytucjonalnych, a także oszacowanie efektywności tego systemu, biorąc pod uwagę wskaźniki oraz dane statystyczne opracowane i udostępnione przez Ministerstwo Spraw Wewnętrznych w konfrontacji z postulatami podnoszonymi przez środowiska mniejszościowe. Celem publikacji będzie ponadto określenie najsłabszych elementów systemu bezpieczeństwa mniejszości narodowych i etnicznych w Polsce oraz wskazanie ich ewentualnych przyczyn.
\end{abstract}

SŁOWA KLUCzowE: zarządzanie bezpieczeństwem, mniejszości narodowe i etniczne, bezpieczeństwo kulturowe, prawa mniejszości, bezpieczeństwo społeczne

\section{THE MANAGEMENT OF NATIONAL AND ETHNIC MINORITIES' SAFETY IN POLAND - EFFICIENCY ASSESSMENT}

\begin{abstract}
The issues of national and ethnic minorities are one of the elements of the state's security policy as well as the determinant of security on an international scale. This is a particularly important issue at the time of increased migration on the European continent. The purpose of this article is to present the assumptions of the management for Polish national and ethnic minorities' safety system, define its legal and institutional framework, as well as assess the effectiveness of this system, taking into account indicators and statistical data developed by the Ministry of the Interior in confrontation with the demands raised by the minority communities. The purpose of the publication is to identify the weakest elements of this system and to indicate their possible causes.
\end{abstract}

KEYWORDS: security management, national and ethnic minorities, cultural security, minority rights, social security

\footnotetext{
${ }^{1}$ Rzeszów University of Technology; Poland.
} 


\section{WPROWADZENIE}

Problematyka mniejszości narodowych i etnicznych to istotny element polityki bezpieczeństwa państwa, szczególnie obecnie, w czasach wzmożonych ruchów migracyjnych na kontynencie europejskim i przenikania się na jednym obszarze wielu narodowości i wielu kultur. Prawidłowe rozwiązania w tym zakresie, czy to na szczeblu prawodawstwa międzynarodowego, czy krajowego, stanowią warunek bezkonfliktowego egzystowania różnorodnych etnicznie społeczności. To także swego rodzaju miernik kondycji demokracji w danym państwie. Jak słusznie podnosi się w literaturze tematu, demokrację postrzega się obecnie właśnie przez pryzmat zdolności społeczeństwa do zapewnienia funkcjonującym w jego ramach mniejszościom możliwości realizacji należnych im uprawnień i swobód, manifestacji swojej odrębności i wyboru metod potwierdzenia własnej tożsamości ${ }^{2}$. Należy zatem zaznaczyć, że optymalne rozwiązania w zakresie społeczności mniejszościowych służyć powinny nie tylko zapewnieniu spokojnej egzystencji tych grup wśród odmiennej etnicznie, narodowościowo, religijnie czy językowo większości, lecz także gwarantować możliwość podtrzymania i pielęgnowania tych różnic, które stanowią istotę ich tożsamości.

Celem niniejszej publikacji jest przedstawienie założeń systemu zarządzania bezpieczeństwem mniejszości narodowych i etnicznych w Polsce, określenie jego ram prawnych oraz instytucjonalnych, a także oszacowanie efektywności tego systemu, biorąc pod uwagę wskaźniki oraz dane statystyczne opracowane i udostępnione przez Ministerstwo Spraw Wewnętrznych w konfrontacji z postulatami podnoszonymi przez środowiska mniejszościowe. Metodą badawczą zastosowaną w celu osiągnięcia założonych celów jest metoda prawnodogmatyczna, bazująca na analizie dostępnej literatury przedmiotu i obowiązujących aktów normatywnych, jak również analiza danych statystycznych dotyczących sytuacji społeczności mniejszościowych w Polsce na przestrzeni ostatnich trzynastu lat.

\section{BEZPIECZEŃSTWO MNIEJSZOŚCI NARODOWYCH I ETNICZNYCH W KONTEKŚCIE BEZPIECZEŃSTWA SPOŁECZNEGO ORAZ KULTUROWEGO}

Pojęcie bezpieczeństwa stanowi kategorię o charakterze interdyscyplinarnym, będącą przedmiotem zainteresowania wielu dziedzin prawa, jak również innych dyscyplin naukowych. Nawiązując do etymologii pojęcia „bezpieczeństwo” zaznaczyć należy, że wywodzi się ono jeszcze z czasów rzymskich - w języku łacińskim se cura oznaczało „wolny od troski”3. Z kolei

\footnotetext{
2 M. Safjan, Pozycja mniejszości w Polsce w świetle orzecznictwa Trybunału Konstytucyjnego, s. 1, https://www.google.com/url?sa=t\&rct=j\&q=\&esrc=s\&source=web\&cd=1\&cad=rja\&uact=8\&ved=2ahUKEwirn bGB4oLjAhVJposKHcL9DKsQFjAAegQIARAC\&url=https\%3A\%2F\%2Ftrybunal.gov.pl\%2Ffileadmin\%2Fco ntent $\% 2$ Fdokumenty\%2Fwystapienia\%2F1998_2006\%2F20031003.pdf\&usg=AOvVaw3Z8w5x3IU2Fmm6JdKCbFp (24.06.2019).

${ }^{3}$ J. Czaputowicz, Bezpieczeństwo międzynarodowe- współczesne koncepcje, Warszawa 2012, s. 22.
} 
potoczne rozumienie terminu „bezpieczeństwo" nawiązuje do jego dosłownego znaczenia i wywodzi się z wyrażenia „bez pieczy”, gdzie piecza oznacza troskę, kontrolę i opiekę ${ }^{4}$.

W literaturze podnosi się, że w zasadzie nie istnieje jedna, wspólnie uzgodniona i przyjęta definicja bezpieczeństwa, a próby określenia pojęcia „bezpieczeństwo” opierają się na stwierdzeniach, iż jest to stan wolności od zagrożeń, strachu lub ataku ${ }^{5}$

Należy zaznaczyć, że pojęcie bezpieczeństwa rozpatrywane jest w wielu kontekstach i ujęciach, m.in. jako bezpieczeństwo międzynarodowe, bezpieczeństwo narodowe czy bezpieczeństwo publiczne. To ostatnie określane jest w definicjach pozytywnych jako stan faktyczny wewnątrz państwa, który umożliwia bez narażenia na szkody (wywołane zarówno zachowaniem ludzi, jak i działaniem sił natury, techniki itp.) normalne funkcjonowanie organizacji państwowej i realizacje jej interesów, zachowanie życia, zdrowia, mienia jednostek żyjących w tej organizacji oraz korzystanie przez te jednostki z praw i swobód zagwarantowanych konstytucją oraz innymi przepisami prawa ${ }^{6}$. Z kolei bezpieczeństwo publiczne w ujęciu negatywnym definiuje się jako ,stan braku zagrożenia dla funkcjonowania organizacji państwowej i realizacji jej interesów, umożliwiający normalny, swobodny jej rozwój”7 . W świetle powyższych ustaleń należy stwierdzić, że bezpieczeństwo publiczne jest jedną z nadrzędnych wartości w państwie i w zasadzie stanowi ratio legis większości rozwiązań normatywnych, a problematyka bezpieczeństwa dotyka wielu dziedzin życia społecznego. W zależności od tego, którego aspektu funkcjonowania państwa i jednostki dotyczy, wyróżnić można m.in. bezpieczeństwo gospodarcze, bezpieczeństwo energetyczne, bezpieczeństwo ekologiczne, bezpieczeństwo komunikacyjne, bezpieczeństwo transportowe, bezpieczeństwo zdrowotne, bezpieczeństwo socjalne, bezpieczeństwo edukacyjne, bezpieczeństwo polityczne, bezpieczeństwo społeczne czy bezpieczeństwo kulturowe ${ }^{8}$.

Bezpieczeństwo społeczne definiowane jest w literaturze tematu m.in. jako element bezpieczeństwa publicznego i całokształt działań prawnych i organizacyjnych realizowanych przez podmioty rządowe, pozarządowe i samych obywateli, które mają na celu zapewnienie określonego poziomu życia osobom, rodzinom, grupom społecznym oraz niedopuszczenie do ich marginalizacji i wykluczenia społecznego. Istotnym elementem bezpieczeństwa społecznego jest tworzenie warunków rozwojowych poprzez możliwość aktywnego uczestnictwa w edukacji, kulturze i szeroko rozumianym życiu społecznym ${ }^{9}$. W literaturze tematu podnosi się, że wyróżnić należy dwie podkategorie bezpieczeństwa społecznego, mianowicie bezpieczeństwo społeczne państwa i bezpieczeństwo społeczne jednostki ${ }^{10}$. Elementem bezpieczeństwa społecznego (a w szczególności tego odnoszącego się do jednostek) jest nie tylko prawo obywateli do godnej

\footnotetext{
${ }^{4}$ P. Turczyński, Bezpieczeństwo europejskie. Systemy, instytucje, funkcjonowanie, Warszawa 2011, s. 15.

${ }^{5}$ J. Stańczyk, Współczesne pojmowanie bezpieczeństwa, Warszawa 1996, s. 16.

${ }^{6}$ J. Zaborowski, Prawne środki zapewnienia bezpieczeństwa i porzadku publicznego, Warszawa 1977, s. 129-130.

${ }^{7}$ A. Misiuk, Administracja porządku i bezpieczeństwa publicznego. Zagadnienia prawno-ustrojowe, Warszawa 2008, s. 17.

${ }^{8}$ E. Kurzępa, Prawna ochrona języka jako aspekt bezpieczeństwa kulturowego [w:] M. Getling, I. Wojaczek (red.), Człowiek-społeczeństwo-bezpieczeństwo. Wybrane aspekty, Przemyśl 2018, s. 190-191.

${ }^{9}$ M. Leszczyński, Bezpieczeństwo społeczne Polaków wobec wyzwań XXI wieku, Warszawa 2011, s. 58.

${ }^{10}$ A. Jagiełło-Szostak, N. Sienko, T. Szyszlak, Konflikty kulturowe a bezpieczeństwo. Mniejszości etniczne-ludy tubylcze-uchodźcy w przestrzeni postkomunistycznej, Wrocław 2018, s. 24.
} 
egzystencji poprzez zaspokojenie podstawowych potrzeb bytowych, lecz także prawo jednostek, w tym członków społeczności mniejszościowych, do uczestnictwa w życiu kulturalnym oraz dostępie do oświaty. Należy zaznaczyć, że wśród zagrożeń bezpieczeństwa społecznego wymienia się m.in. uprzedzenia kulturowe i religijne, jak również dyskryminację mniejszości narodowych, etnicznych, kulturowych, językowych i religijnych ${ }^{11}$.

Warto wskazać ponadto na wyodrębnienie w ostatnim czasie w literaturze tematu kategorii bezpieczeństwa kulturowego jako elementu bezpieczeństwa publicznego. Za prekursora tego pojęcia na gruncie polskiej doktryny uważa się Jana Czaję, który bezpieczeństwo kulturowe każe rozumieć jako „zdolność państwa do ochrony tożsamości kulturowej, dóbr kultury i dziedzictwa narodowego, w warunkach otwarcia na świat, umożliwiających rozwój kultury poprzez internalizację wartości niesprzecznych z własną tożsamością,"12. Odnosząc to pojęcie do problematyki mniejszości narodowych i etnicznych uznać należy, że elementem bezpieczeństwa kulturowego państwa jest m.in. możliwość swobodnego pielęgnowania i podtrzymywania własnej narodowej, etnicznej czy kulturowej tożsamości społeczności mniejszościowych, niezależnie od wartości przyjętych przez większość społeczeństwa, wśród której przedstawiciele mniejszości egzystują.

Wobec powyższych rozważań można postawić tezę, że bezpieczeństwo mniejszości to stan, kiedy społeczności mniejszościowe (chodzi przede wszystkim o mniejszości narodowe i etniczne) mają zapewnioną możliwość równoprawnego współegzystowania obok społeczności większościowej na danym terytorium i realizowania swoich potrzeb zarówno w sferze socjalnej i bytowej, jak i w zakresie podtrzymywania kulturowych, językowych i religijnych odrębności oraz pielęgnowania własnej narodowej lub etnicznej tożsamości, a także swobody w wyrażaniu tej odrębności zarówno w sferze prywatnej, jak i publicznej. Pojęcie bezpieczeństwa mniejszości narodowych i etnicznych poprzez swój zakres przedmiotowy oscyluje zatem na pograniczu bezpieczeństwa społecznego oraz bezpieczeństwa kulturowego.

Nie ulega wątpliwości, że opracowanie ram skutecznego systemu bezpieczeństwa państwa nie może obyć się bez stosownych gwarancji na rzecz mniejszości narodowych i etnicznych. Konflikty na tle narodowościowym i etnicznym, ograniczające się w swojej początkowej fazie to obszaru danego państwa, wielokrotnie eskalowały poza jego granice, doprowadzając do konfliktów o charakterze międzynarodowym. Zatem efektywne zarządzanie bezpieczeństwem mniejszości nie tylko stanowi jeden z komponentów bezpieczeństwa wewnętrznego, lecz także jest gwarancją tego pożądanego stanu w skali międzynarodowej.

11 A. Skrabacz, Uwarunkowania tworzenia bezpieczeństwa społecznego w XXI wieku [w:] A. Skrabacz, S. Sulowski (red.), Bezpieczeństwo społeczne. Pojęcia-Uwarunkowania-Wyzwania, Warszawa 2012, s. 54.

12 J. Czaja, Kulturowe czynniki bezpieczeństwa, Kraków 2008, s. 36-37. 


\section{SYSTEM ZARZĄDZANIA BEZPIECZEŃSTWEM MNIEJSZOŚCI NARODOWYCH I ETNICZNYCH W POLSCE - GŁÓWNE ZAŁOŻENIA}

Za zarządzanie bezpieczeństwem uznaje się w literaturze tematu zespół działań dążących do osiągnięcia zamierzonego stanu bezpieczeństwa oraz utrzymywania go na określonym poziomie. Służą one minimalizacji prawdopodobieństwa wystąpienia zdarzeń niepożądanych i stwarzają możliwość ich kontrolowania i monitorowania poprzez identyfikację zagrożeń oraz ocenę występującego ryzyka ${ }^{13}$. Ramy systemu bezpieczeństwa mniejszości w Polsce tworzą prawne regulacje szczebla krajowego i międzynarodowego, których założenia są z kolei wykonywane przez organy administracji rządowej i samorządowej, jak również instytucje i podmioty nienależące do sektora publicznego. Jeśli chodzi o najpoważniejsze zagrożenia dla bezpieczeństwa społeczności mniejszościowych, którym poszczególne elementy systemu powinny zapobiegać lub je eliminować, to należy wymienić przede wszystkim dążenie do asymilacji takich grup z resztą społeczeństwa wbrew ich woli (przede wszystkim pod względem kulturowym), wykluczenie czy marginalizację w sferze życia publicznego, pozbawienie możliwości edukacji w zakresie własnej historii, tradycji i języka, jak również brak dostępu do elementów tej kultury i brak możliwości jej pielęgnowania.

Swoisty system zarządzania bezpieczeństwem mniejszości narodowych i etnicznych opracowany został w Polsce po transformacji ustrojowej w 1989 roku, kiedy Rzeczpospolita Polska stała się sygnatariuszem konwencji międzynarodowych dotyczących ochrony praw człowieka, obejmujących swoim zakresem również ochronę społeczności mniejszościowych. Konieczne stało się wówczas dostosowanie prawodawstwa krajowego do standardów międzynarodowych. Wskazać należy w szczególności na konwencje opracowane w ramach Rady Europy, które w całości poświęcono społecznościom mniejszościowym i które stanowią najistotniejsze multilateralne rozwiązania w tym zakresie. Chodzi przede wszystkim o ratyfikowaną przez Polskę w 2000 roku Konwencję ramową o ochronie mniejszości narodowych ${ }^{14}$ oraz Europejską Kartę Języków Regionalnych lub Mniejszościowych. Ten drugi akt prawa międzynarodowego Polska ratyfikowała w 2009 roku ${ }^{15}$. Wśród rozwiązań międzynarodowych, które pośrednio dotyczą problematyki społeczności mniejszościowych, wyróżnić można również Europejską Konwencję o Ochronie Praw Człowieka i Podstawowych Wolności ${ }^{16}$, Międzynarodowy Pakt Praw Obywatelskich i Politycznych ${ }^{17}$ czy Międzynarodową Konwencję w sprawie likwidacji wszelkich form dyskryminacji rasowej ${ }^{18}$. Duże znaczenie w kwestii kształtowania systemu ochrony praw mniejszości w Polsce miał również udział w pracach KWWE/OBWE czy późniejsze negocjacje akcesyjne $\mathrm{z}$ Unią Europejską ${ }^{19}$. Polska jest również stroną wielu bilateralnych umów

\footnotetext{
${ }^{13}$ A. Białas, Bezpieczeństwo informacji i ustug w nowoczesnej instytucji i firmie, Warszawa 2007, s. 217 i nast.

${ }^{14}$ Dz. U. z 2002 roku, Nr 22, poz. 209.

15 Dz. U. z 2009 roku, Nr 137, poz. 1121.

${ }^{16}$ Dz. U. z 1993 roku, Nr 63, poz. 285.

${ }^{17}$ Dz. U. z 1977, poz. 38, poz. 167.

${ }^{18}$ Dz. U. z 1969 roku, Nr 25, poz. 187.

${ }^{19}$ G. Janusz, Ochrona praw mniejszości narodowych w Europie, Lublin 2011, s. 16.
} 
międzynarodowych, które w pewnym stopniu, choć zazwyczaj dość lakonicznie, odnoszą się do problematyki mniejszości zamieszkujących w danych państwach.

Należy zaznaczyć, że swój wielonarodowościowy charakter Polska utraciła po II wojnie światowej na skutek okupacyjnej polityki III Rzeszy, która doprowadziła do zagłady znacznej części mniejszości żydowskiej oraz romskiej, i obecnie jest państwem stosunkowo homogenicznym pod względem narodowościowym, co być może czyni zorganizowanie optymalnego systemu ochrony praw mniejszości prostszym niż w państwach multikulturowych, różnorodnych narodowościowo i etnicznie. Według Narodowego Spisu Powszechnego z 2011 roku ludność o wyłącznie polskich identyfikacjach narodowościowych obejmowała blisko 37394 tys. osób, co stanowi 97,1 \% mieszkańców Polski. Ponad 871 tys. osób zadeklarowało zarówno polską, jak i inną niż polska tożsamość narodowo-etniczną. Deklarujący wyłącznie niepolską przynależność narodową lub etniczną stanowią grupę przeszło 596 tys. osób (więcej niż podczas Narodowego Spisu Powszechnego w 2002 roku - wówczas narodowość wyłącznie niepolską zadeklarowało 445 tys. obywateli polskich $\left.{ }^{20}\right)^{21}$. Podczas spisu w 2011 roku najwięcej osób jako inną narodowość niż polska wskazało narodowość śląską - 846,7 tys. mieszkańców Polaki, w dalszej kolejności kaszubską - 232,5 tys., niemiecką - 147,8 tys., ukraińską - 51 tys., białoruską - 46,8 tys., romską - 17 tys., rosyjską - 13 tys., amerykańską - 11,8tys., angielską - 10,5 tys., łemkowską - 10,5 tys., włoską - 8,6 tys., francuską - 8 tys., litewską - 7,9 tys., żydowską $-7,5$ tys., hiszpańską -4 tys., wietnamską -4 tys., holenderską $-3,9$ tys., grecką $-3,6$ tys., ormiańską $-3,6$ tys., czeską $-3,4$ tys., słowacką $-3,2$ tys., kociewską $-3,1$ tys. ${ }^{22}$.

Odnosząc się do rozwiązań krajowego porządku prawnego należy zaznaczyć, że już na szczeblu konstytucyjnym zawarto gwarancje na rzecz społeczności mniejszościowych. Zgodnie z art. 35 ust. 1 Konstytucji RP z 1997 roku Rzeczpospolita Polska zapewnia obywatelom polskim należącym do mniejszości narodowych i etnicznych wolność zachowania i rozwoju własnego języka, zachowania obyczajów i tradycji oraz rozwoju własnej kultury ${ }^{23}$. Z kolei w myśl ust. 2 mniejszości narodowe i etniczne mają prawo do tworzenia własnych instytucji edukacyjnych, kulturalnych i instytucji służących ochronie tożsamości religijnej oraz do uczestnictwa w rozstrzyganiu spraw dotyczących ich tożsamości kulturowej. Uprawnienia mniejszości w zakresie języka określa ponadto art. 27 ustawy zasadniczej, zgodnie z którym w Rzeczypospolitej Polskiej językiem urzędowym jest język polski. Przepis ten nie narusza praw mniejszości narodowych wynikających z ratyfikowanych umów międzynarodowych.

\footnotetext{
${ }^{20}$ Wyniki Narodowego Spisu Powszechnego Ludności i Mieszkań w 2002 roku w zakresie deklarowanej narodowości oraz języka używanego w domu, Główny Urząd Statystyczny https://stat.gov.pl/spisypowszechne/narodowe-spisy-powszechne/narodowy-spis-powszechny-2002/wyniki-narodowego-spisupowszechnego-2002-narodowosci-oraz-jezyka/ (28.06.2019).

${ }^{21}$ W spisie ludności z 2011 roku po raz pierwszy w historii polskich spisów powszechnych umożliwiono mieszkańcom Polski wyrażanie złożonych tożsamości narodowo-etnicznych poprzez zadawanie osobom spisywanym dwóch pytań o przynależność narodowo-etniczną (Struktura narodowo-etniczna, językowa i wyznaniowa ludności Polski. Narodowy Spis Powszechny Ludności i Mieszkań 2011, Główny Urząd Statystyczny, Warszawa 2015, s. 19.

22 S. Łodziński, K. Warmińska, G. Gudaszewski, Mniejszości narodowe i etniczne w Polsce w świetle Narodowego Spisu Powszechnego Ludności z 2011 roku, Warszawa 2015, s. 65-66.

${ }^{23}$ Dz. U. z 1997 roku, Nr 78, poz. 483 z późn. zm.
} 
Z kolei najważniejszym aktem rangi ustawowej, który określa normatywne ramy systemu bezpieczeństwa mniejszości narodowych i etnicznych w Polsce i wyznacza najważniejsze standardy w tej dziedzinie, jest ustawa z dnia 6 stycznia 2005 roku o mniejszościach narodowych $\mathrm{i}$ etnicznych oraz o języku regionalnym, która w całości poświęcona została tej problematyce ${ }^{24}$. Jest to pierwszy tego typu akt normatywny w polskim porządku prawnym, który - jak podnosi się $\mathrm{w}$ literaturze przedmiotu - w zestawieniu $\mathrm{z}$ tego typu regulacjami innych państw europejskich plasuje się na pewno powyżej średniej ${ }^{25}$. W uzasadnieniu projektu ustawy zaznaczono, że celem aktu prawnego jest określenie praw i obowiązków osób należących do mniejszości. W szczególności zaakcentowano potrzebę unormowania uprawnień o charakterze społecznym i oświatowo-kulturalnym, choć należy zaznaczyć, że uprawnienia społeczności mniejszościowych w sferze oświaty były zagwarantowane w polskim porządku prawnym jeszcze przed uchwaleniem ustawy o mniejszościach narodowych i etnicznych, na gruncie ustawy o systemie oświaty z dnia 7 września 1991 roku $^{26}$.

Trzeba zauważyć, że polski ustawodawca rozróżnia (czy to na gruncie Konstytucji RP z 1997 roku, czy na gruncie ustawy z dnia 6 stycznia 2005 roku o mniejszościach narodowych i etnicznych oraz o języku regionalnym) dwa rodzaje społeczności mniejszościowych, które objęto szczególną ochroną - mniejszość narodową oraz mniejszość etniczną. Jedyna legalna definicja mniejszości narodowych i etnicznych określona została na gruncie wspomnianej wcześniej ustawy o mniejszościach narodowych i etnicznych oraz o języku regionalnym.

Za mniejszość narodową uznano na gruncie ustawy następujące mniejszości: białoruską, czeską, litewską, niemiecką, ormiańską, rosyjską, słowacką, ukraińską, żydowską. Za mniejszości etniczne uznaje się z kolei mniejszości: karaimską, łemkowską, romską, tatarską.

Należy zatem stwierdzić, że czynnikiem odróżniającym mniejszość narodową od mniejszości etnicznej jest $\mathrm{w}$ zasadzie kwestia utożsamiania się z narodem zorganizowanym we własnym państwie (mniejszość narodowej) oraz brak utożsamiania się z narodem zorganizowanym we własnym państwie (mniejszość etniczna), a także świadomość własnej historycznej wspólnoty narodowej (mniejszości narodowe) bądź etnicznej (mniejszości etniczne). Sposób określania na gruncie ustawowym zarówno definicji mniejszości narodowych, jak i mniejszości etnicznych zbliżony w swojej konstrukcji do rozwiązań węgierskich w tym zakresie, jest raczej rzadkością w ustawodawstwach innych państw europejskich, szczegółowe omówienie problematyki definiowania mniejszości przekracza jednak ramy niniejszej publikacji i stanowić może temat odrębnych badań ${ }^{27}$. Należy zaznaczyć, że najliczniejszą spośród mniejszości jest mniejszość

\footnotetext{
${ }^{24}$ Dz. U. z 2017 roku, poz. 823 z późn. zm.

${ }^{25}$ G. Janusz, op. cit., s. 624.

26 http://orka.sejm.gov.pl/Druki4ka.nsf/(\$vAllByUnid)/231AB306399466C2C1256B4C002C3DD7/\$file/223.pdf (27.06.2019).

${ }^{27}$ S. Maksimiec, Mniejszości narodowe i etniczne w krajach Europy Środkowej $i$ Wschodniej po przystapieniu do Unii Europejskiej, Warszawa 2012, s. 63.
} 
niemiecka (ok. 144236 osób) oraz mniejszość białoruska (43878 osób), najmniej liczną zaś jest mniejszość ormiańska (1683) i karaimska (314 osób) ${ }^{28}$.

Spośród gwarancji przewidzianych w ustawie o mniejszościach narodowych i etnicznych z dnia 6 stycznia 2005 roku zwrócić należy uwagę przede wszystkim na szereg uprawnień o charakterze językowym, na których szczególnie zależało społecznościom mniejszościowym. Chodzi przede wszystkim o możliwość używania pisowni swoich imion i nazwisk zgodnie z zasadami pisowni języka mniejszości, w szczególności do rejestracji w aktach stanu cywilnego i dokumentach tożsamości (art. 7 ust. 1), prawo do swobodnego posługiwania się językiem mniejszości w życiu prywatnym i publicznie (art. 8 pkt 1), prawo do używania języka mniejszości jako języka pomocniczego przed organami gminy (art. 9 ust. 1), prawo do nauki języka mniejszości lub w języku mniejszości (art. 8 pkt 4) czy prawo do używania dodatkowych tradycyjnych nazw w języku mniejszości obok urzędowych nazw miejscowości i obiektów fizjograficznych i nazw ulic (art. 12 ust. 1).

Zaznaczyć trzeba, że pewne obawy społeczności mniejszościowych budzi dodanie do przepisów wyżej wymienionej ustawy postanowienia, zawartego na gruncie art. 1, dotyczącego integracji obywatelskiej i społecznej osób należących do mniejszości narodowych i etnicznych, jako jednego z celów ustawy ${ }^{29}$. Taki zapis budzi obawy zainteresowanych społeczności o ewentualną ,przymusową” niejako asymilację z większościową częścią społeczeństwa, choć wydaje się, że na chwilę obecną takie działania pozostają jedynie w sferze spekulacji.

Wskazać należy również na inne akty normatywne stanowiące ramy prawne systemu bezpieczeństwa mniejszości. Chodzi w szczególności o ustawę o systemie oświaty z dnia 7 września 1991 roku (w art. 13 ust. 1 zagwarantowano uczniom prawo do podtrzymywania poczucia tożsamości narodowej, etnicznej, językowej i religijnej, a w szczególności nauki języka oraz własnej historii i kultury) ${ }^{30}$, ustawę o radiofonii i telewizji z dnia 29 grudnia 1992 roku (określenie obowiązków nadawców radiowych i telewizyjnych w zakresie przestrzegania ram czasowych nadawanych audycji w języku mniejszości) ${ }^{31}$ czy ustawę z dnia 7 kwietnia 1989 roku Prawo o stowarzyszeniach (gwarancja swobody w rejestracji stowarzyszeń członków mniejszości narodowych i etnicznych - zniesiono wcześniej stosowaną zasadę koncesjonowania stowarzyszeń dla mniejszości) ${ }^{32}$. Normatywne ramy systemu ochrony mniejszości tworzy także szereg aktów wykonawczych.

Jeżeli chodzi natomiast o instytucjonalne ramy systemu ochrony praw mniejszości narodowych i etnicznych, to należy zaznaczyć, że określono je przede wszystkim w rozdziale 5 ustawy o mniejszościach narodowych i etnicznych oraz o języku regionalnym. W ich zakres

\footnotetext{
${ }^{28}$ Mniejszości narodowe i etniczne oraz społeczność posługująca się językiem kaszubskim - liczebność (również $w g \quad$ województw),http://mniejszosci.narodowe.mswia.gov.pl/mne/mniejszosci/wyniki-narodowego-spis/699 9,Mniejszosci-narodowe-i-etniczne-oraz-spolecznosc-poslugujaca-sie-jezykiem-kaszub.html (1.07.2019).

${ }^{29}$ Ustawa z dnia 30 maja 2014 roku o zmianie ustawy o mniejszościach narodowych i etnicznych oraz o języku regionalnym oraz ustawy o działach administracji rządowej (Dz. U. z 2014 roku, poz. 829).

${ }^{30}$ Dz. U. z 2018 roku, poz. 1457 z późn. zm.

${ }^{31}$ Dz. U z 209 roku, poz. 361.

32 Dz. U. z 2019 roku, poz. 713.
} 
wchodzą zarówno organy rządowe, samorządowe, jak i podmioty spoza sfery publicznej tworzone przez członków społeczności mniejszościowych.

Zgodnie $\mathrm{z}$ art. 21 ust. 1 ustawy organem administracji rządowej w sprawach objętych ustawą jest minister właściwy do spraw wyznań religijnych oraz mniejszości narodowych i etnicznych. Należy zaznaczyć, że dział wyznania religijne oraz mniejszości narodowe i etniczne wchodzi obecnie w zakres kompetencji Ministra Spraw Wewnętrznych i Administracji, a jednym z departamentów Ministerstwa Spraw Wewnętrznych i Administracji jest Departament Wyznań Religijnych oraz Mniejszości Narodowych i Etnicznych ${ }^{33}$. W myśl art. 21 ust. 2 ustawy o mniejszościach narodowych i etnicznych oraz o języku regionalnym minister właściwy do spraw wyznań religijnych oraz mniejszości narodowych i etnicznych w szczególności sprzyja realizacji praw i potrzeb mniejszości poprzez podejmowanie działań na rzecz mniejszości i inicjowanie programów dotyczących zachowania i rozwoju tożsamości, kultury i języka mniejszości, realizacji zasady równego traktowania osób bez względu na pochodzenie etniczne czy integracji obywatelskiej i społecznej. Ponadto minister ten współdziała z właściwymi organami w zakresie przeciwdziałania naruszaniu praw mniejszości, a także upowszechnia wiedzę na temat mniejszości oraz ich kultury oraz inicjuje badania nad sytuacją mniejszości, w tym w zakresie dyskryminacji (art. 21 ust. 2).

$\mathrm{Z}$ kolei na terenie województwa to wojewoda koordynuje działania organów administracji rządowej, realizujących zadania na rzecz mniejszości, podejmuje działania na rzecz respektowania praw mniejszości i przeciwdziałania naruszaniu tych praw i dyskryminacji osób należących do mniejszości czy podejmuje działania na rzecz rozwiązywania problemów mniejszości (art. 22 ust. 1). Wojewoda współdziała $\mathrm{z}$ organami samorządu terytorialnego i organizacjami społecznymi, w szczególności z organizacjami mniejszości, oraz opiniuje programy na rzecz „mniejszości realizowane na terenie danego województwa” (art. 22 ust. 2). Wojewoda może ustanowić pełnomocnika do spraw mniejszości narodowych i etnicznych. Na chwilę obecną w każdym województwie ustanowiony został taki pełnomocnik ${ }^{34}$.

„Wpływ na kształt polityki państwa wobec mniejszości mają także instytucje takie jak: Komisja Wspólna Rządu i Mniejszości Narodowych i Etnicznych jako organ opiniodawczodoradczy Prezesa Rady Ministrów, Wydział Mniejszości Narodowych i Etnicznych oraz Departament Wyznań Religijnych oraz Mniejszości Narodowych i Etnicznych ${ }^{35}$. Należy podkreślić, że w skład Komisji Wspólnej Rządu i Mniejszości Narodowych i Etnicznych,

\footnotetext{
${ }^{33} \mathrm{https}: / /$ www.gov.pl/web/mswia (29.06.2019).

$34 \mathrm{http} / / /$ mniejszosci.narodowe.mswia.gov.pl/mne/mniejszosci/podmioty-odpowiedzialn/pelnomocnicywojewodow/6488,Osoby-odpowiedzialne-za-sprawy-mniejszosci-narodowych-i-etnicznych-w-wojewodztwa.html (30.06.2019).

${ }^{35}$ M. Campion, K. Pabis, Bezpieczeństwo kulturowe mniejszości narodowych i etnicznych w Polsce. Wybrane problemy na przykładzie mniejszości karaimskiej, s. $235 \mathrm{https} / /$ www.google.com/url?sa=t\&rct=j\&q=\&esrc=s\&sour ce $=$ web $\&$ cd $=2 \&$ cad $=$ rja\&uact $=8 \&$ ved $=2$ ahUKEwiF6o6T4JHjAhWvlIsKHR-

7Cn4QFjABegQIAhAC\&url=http\%3A\%2F\%2Frep.up.krakow.pl\%2Fxmlui\%2Fbitstream $\% 2$ Fhandle $\% 2 F 11716 \% 2 F 67$ 3\%2F0056_20150617_ra_bezpieczenstwo_kulturowe_mniejszosci_k_pabis.pdf\%3Fsequence\%3D1\%26isAllowed\%3D y\&usg=AOvVaw3TJTx 5852 vipNkyVgst $\bar{M}-x(30.06 . \overline{2019})$.
} 
oprócz przedstawicieli organów administracji rządowej, wchodzą przedstawiciele każdej mniejszości narodowej i etnicznej” (art. 24 ust. 1 pkt 2).

„Możliwość realizacji szeregu uprawnień dla społeczności mniejszościowych przez powołane do tego wyżej określone organy zależy w główniej mierze od środków finansowych przyznawanych poszczególnym grupom. Środki te są przyznawane bądź w formie dotacji podmiotowych, bądź dotacji celowych. Dysponentem tych pierwszych jest minister właściwy do spraw wyznań religijnych oraz mniejszości narodowych i etnicznych i są one przyznawane z budżetu państwa. Dotacje te mogą otrzymywać organizacje mniejszości lub mające istotne znaczenie dla kultury mniejszości instytucje kulturalne (art. 18 ust. 5). Dotacje celowe także pochodzą z budżetu państwa, są one jednak przekazywane poszczególnym jednostkom samorządu terytorialnego, które dokonują ich rozdysponowania w celu realizacji zadań związanych ze wspieraniem społeczności mniejszościowych. Taka forma udzielanego wsparcia finansowego budzi zastrzeżenia zainteresowanych grup, co wskazane zostanie także w późniejszych wywodach. Należy również zaznaczyć, że środkami przyznawanymi na rzecz środowisk mniejszościowych mogą być również środki przekazywane bezpośrednio z budżetu jednostki samorządu terytorialnego organizacjom lub instytucjom realizującym zadania służące ochronie, zachowaniu i rozwojowi tożsamości kulturowej mniejszości lub integracji obywatelskiej lub społecznej (art. 18 ust. 4). Dane o tych ostatnich nie są uwzględnienie w okresowych raportach dotyczących sytuacji mniejszości w Polsce.

\section{SYSTEM BEZPIECZEŃSTWA MNIEJSZOŚCI NARODOWYCH I ETNICZNYCH W POLSCE - EFEKTYWNOŚĆ}

W świetle powyższych rozważań można uznać, że system bezpieczeństwa społeczności mniejszościowych w Polsce posiada solidne ramy normatywne oraz instytucjonalne i z pewnością wyróżnia się na tle rozwiązań innych państw europejskich. Kluczowe jednak wydaje się praktyczne realizowanie przez umocowane do tego organy gwarancji zapewnionych na gruncie przepisów prawa. Jedynie $\mathrm{w}$ ten sposób można zweryfikować słuszność przyjętych przez ustawodawcę rozwiązań.

W kwestii oceny realizacji uprawnień językowych należy dokonać analizy publicznie dostępnych rejestrów, tj. Rejestru Gmin, na których obszarze są używane nazwy w języku mniejszości, oraz Urzędowego Rejestru Gmin, w których jest używany język pomocniczy ${ }^{36}$. Trzeba zaznaczyć, że minister właściwy do spraw wyznań religijnych oraz mniejszości narodowych i etnicznych periodycznie opracowuje i publikuje raporty dotyczące sytuacji mniejszości narodowych i etnicznych oraz języka regionalnego w Rzeczypospolitej Polskiej zawierające sprawozdanie $\mathrm{z}$ realizacji praw mniejszości. Istotne $\mathrm{w}$ zakresie oszacowania efektywności systemu bezpieczeństwa mniejszości są także publicznie dostępne zestawienia

\footnotetext{
36 http://mniejszosci.narodowe.mswia.gov.pl/mne/rejestry/urzedowy-rejestr-gmin/6884,Urzedowy-Rejestr-Gmin-wktorych-jest-uzywany-jezyk-pomocniczy.html (30.06.2019).
} 
dotacji podmiotowych i celowych przyznawanych przez ministra właściwego do spraw wyznań religijnych oraz mniejszości narodowych i etnicznych na realizację gwarancji przyznanych mniejszościom. Zaznaczyć należy, że przeprowadzone analizy wyżej określonych danych obejmują okres od 2005 roku (tj. od kiedy weszła w życie ustawa o mniejszościach narodowych i etnicznych oraz o języku regionalnym z dnia 6 stycznia 2005 roku) do 2018 roku, choć trzeba jednocześnie podkreślić, że ostatnim raportem opublikowanym przez ministra właściwego do spraw wyznań religijnych oraz mniejszości narodowych i etnicznych dotyczącym sytuacji mniejszości jest raport z 2015 roku, więc analiza danych dotyczących wielkości dotacji przekazywanych z budżetu państwa na rzecz społeczności mniejszościowych oraz liczby placówek, w których odbywa się nauczanie języka lub w języku mniejszości, dotyczy lat objętych raportami oraz częściowo roku 2016 (MSWiA opublikowało dane za ten rok dotyczące kwot dotacji przeznaczonych dla społeczności mniejszościowych w IV Raporcie dla Sekretarza Generalnego Rady Europy z realizacji przez Rzeczpospolitą Polską postanowień Konwencji ramowej o ochronie mniejszości narodowych).

Odnosząc się w pierwszej kolejności do realizacji uprawnień językowych społeczności mniejszościowych, należy zaznaczyć, że na dzień 1 lipca 2019 roku liczba gmin wpisanych do Rejestru gmin (na podstawie art. 12 ustawy o mniejszościach narodowych i etnicznych oraz o języku regionalnym z dnia 6 stycznia 2005 r.), na których obszarze używane są nazwy w języku mniejszości wynosi 62. Pierwsza gmina, gmina Radłów w województwie opolskim, została wpisana do rejestru 22 grudnia 2006 roku. Największa aktywność w tym zakresie nastąpiła w latach 2007-2015. W roku 2016 wpisano do rejestru już tylko jedną gminę, w roku 2017 nie uwzględniono w rejestrze ani jednej nowej gminy. W roku 2018 zarejestrowano jedną gminę, a dwie kolejne w marcu 2019 roku, aczkolwiek były to gminy, w których stosuje się nazwy w języku regionalnym, a więc w języku kaszubskim. Spośród wszystkich 62 gmin, aż w 31 gminach stosuje się nazwy w języku niemieckim (przede wszystkim na obszarze województwa opolskiego). W 27 gminach stosowane są nazwy w języku kaszubskim, tj. języku regionalnym. W dwóch gminach stosowane są nazwy w języku łemkowskim, w jednej gminie w języku białoruskim i litewskim ${ }^{37}$.

Wobec powyższych danych można wysnuć wniosek, że z uprawnień językowych w zakresie stosowania nazw miejscowości i ulic w języku mniejszości korzystają w zasadzie trzy mniejszości narodowe (niemiecka, litewska i białoruska) oraz jedna mniejszość etniczna (łemkowska), z czego zdecydowana większość uprawnień w tym zakresie realizowana jest przez mniejszość niemiecką, tj. najliczniejszą mniejszość narodową. Najprawdopodobniej taki stan rzeczy wynika z brzmienia art. 12 ust. 7 ustawy o mniejszościach narodowych i etnicznych oraz o języku regionalnym z dnia 6 stycznia 2005 roku, w myśl którego dodatkowa nazwa miejscowości lub obiektu fizjograficznego w języku mniejszości może być ustalona na wniosek rady gminy, jeżeli liczba mieszkańców gminy należących do mniejszości jest nie mniejsza niż

\footnotetext{
${ }^{37}$ http://mniejszosci.narodowe.mswia.gov.pl/mne/rejestry/rejestr-gmin/6794,Rejestr-gmin-na-ktorych-obszarzesa-uzywane-nazwy-w-jezyku-mniejszosci.html (1.07.2019).
} 
20\% ogólnej liczby mieszkańców tej gminy lub - w przypadku miejscowości zamieszkanej - za ustaleniem dodatkowej nazwy miejscowości w języku mniejszości opowiedziała się w konsultacjach, przeprowadzonych $\mathrm{w}$ trybie określonym w art. 5a ust. 2 ustawy o samorządzie gminnym z dnia 8 marca 1990 r., ponad połowa mieszkańców tej miejscowości biorących $\mathrm{w}$ nich udział. Wynika $\mathrm{z}$ tego, że uprawnienia językowe $\mathrm{w}$ tym zakresie w istocie zarezerwowane są dla stosunkowo licznych mniejszości.

Jeszcze mniej korzystnie prezentuje się sytuacja w zakresie możliwości korzystania zjęzyka mniejszości jako języka pomocniczego przed organami gminy (uprawnienie zagwarantowane na gruncie art. 9 ustawy o mniejszościach narodowych i etnicznych oraz o języku regionalnym). Na dzień 1 lipca 2019 roku liczba gmin wpisanych do Urzędowego Rejestru Gmin, w których jest używany język pomocniczy wyniosła 33 i nie uległa zmianie od 2014 roku. Pierwszą gminą wpisaną do rejestru w dniu 25 stycznia 2006 roku, w której istnieje możliwość stosowania języka mniejszości jako języka pomocniczego, była gmina Radłów w województwie opolskim, gdzie językiem pomocniczym jest język niemiecki. Najwięcej gmin uzyskało wpis do rejestru w latach 2006-2009. W roku 2010 wpis uzyskały już tylko dwie gminy. W roku 2011 żadna gminy nie została wpisana do rejestru, a w roku 2012, 2013 i 2014 wpis uzyskało po jednej gminie. Od roku 2015 nie odnotowano już żadnego wpisu do Urzędowego Rejestru Gmin, w których używany jest język pomocniczy. Należy zaznaczyć, że w zdecydowanej większości wpisanych do rejestru gmin językiem pomocniczym jest język niemiecki (22 gminy w województwie opolskim). W pięciu gminach w województwie podlaskim językiem pomocniczym jest język białoruski, a w jednej gminie (również w województwie podlaskim) językiem pomocniczym jest język litewski. Reszta gmin wpisanych do Urzędowego Rejestru Gmin, w których jest używany język pomocniczy, to gminy w województwie pomorskim, w których stosowany jest język kaszubski, a więc język regionalny ${ }^{38}$.

Z powyższych zestawień wynika zatem, że jedynie trzy mniejszości narodowe korzystają $\mathrm{z}$ uprawnień językowych, z czego dwie, tj. białoruska i litewska w zasadzie w minimalnym zakresie. Takiego uprawnienia nie posiada natomiast żadna mniejszość etniczna. Wydaje się, że taka sytuacja jest spowodowana, podobnie jak w przypadku uprawnień w zakresie podwójnego nazewnictwa miejscowości i ulic, wymogami określonymi na gruncie art. 9 ust. 2 ustawy o mniejszościach narodowych i etnicznych oraz o języku regionalnym, zgodnie z którym język pomocniczy może być używany jedynie w gminach, w których liczba mieszkańców gminy należących do mniejszości, której język ma być używany jako język pomocniczy, jest nie mniejsza niż 20\% ogólnej liczby mieszkańców gminy. Taki wymóg normatywny w zasadzie zamyka drogę do nabycia wyżej wymienionych uprawnień mniej licznym społecznościom mniejszościowym, co również podnoszą środowiska mniejszościowe.

\footnotetext{
38 http://mniejszosci.narodowe.mswia.gov.pl/mne/rejestry/urzedowy-rejestr-gmin/6884,Urzedowy-Rejestr-Gmin-wktorych-jest-uzywany-jezyk-pomocniczy.html (1.07.2019).
} 
Jeżeli chodzi z kolei o wspieranie przez organy władzy publicznej działalności zmierzającej do ochrony, zachowania i rozwoju tożsamości kulturowej mniejszości narodowych i etnicznych, to jego efektywność ocenić można przede wszystkim na podstawie udostępnionych przez Ministerstwo Spraw Wewnętrznych i Administracji danych w zakresie finansowania mniejszości narodowych i etnicznych (chodzi o finansowanie wydatków edukacyjnych oraz dotacje na realizację zadań mających na celu ochronę, zachowanie i rozwój tożsamości kulturowej mniejszości narodowych i etnicznych oraz zachowanie i rozwój języka regionalnego). Ustawa o mniejszościach narodowych i etnicznych oraz o języku regionalnym w art. 18 ust. 2 określa dziesięć grup zadań, na które mogą być przekazywane dotacje. Są to:

1. działalność instytucji kulturalnych, ruchu artystycznego i twórczości mniejszości oraz imprez artystycznych mających istotne znaczenie dla kultury mniejszości;

2. inwestycje służące zachowaniu tożsamości kulturowej mniejszości;

3. wydawanie książek, czasopism, periodyków i druków ulotnych w językach mniejszości lub w języku polskim, w postaci drukowanej oraz w innych technikach zapisu obrazu i dźwięku;

4. wspieranie programów telewizyjnych i audycji radiowych realizowanych przez mniejszości;

5. ochronę miejsc związanych z kulturą mniejszości;

6. działalność świetlicową;

7. prowadzenie bibliotek oraz dokumentacji życia kulturalnego i artystycznego mniejszości;

8. edukację dzieci i młodzieży realizowaną w różnych formach;

9. propagowanie wiedzy o mniejszościach;

10. inne programy mające na celu wspieranie działalności zmierzającej do ochrony, zachowania i rozwoju tożsamości kulturowej mniejszości oraz programy wspierające integrację obywatelską mniejszości.

$\mathrm{Na}$ realizację wyżej wymienionych grup zadań organizacje mniejszości oraz instytucje kulturalne mające istotne znaczenie dla kultury mniejszości mogą otrzymywać dotacje celowe oraz dotacje podmiotowe. Ustawa uwzględniła też specyfikę mniejszości i przewidziała, że dotacje dla nich, o ile są przyznawane z części budżetu państwa, której dysponentem jest minister właściwy do spraw wyznań religijnych oraz mniejszości narodowych i etnicznych, mogą być udzielane z pominięciem otwartego konkursu ofert ${ }^{39}$.

Należy zaznaczyć, że w 2006 roku łączna kwota dotacji celowych i podmiotowych z budżetu państwa na finansowanie społeczności mniejszościowych oraz społeczności posługującej się językiem regionalnym wyniosła 114.961.749,60 zł (z czego subwencja oświatowa wyniosła ogółem 95.717 .785 zł - największa pula przypadła mniejszości niemieckiej, białoruskiej, ukraińskiej, romskiej, litewskiej i słowackiej). Kwota dotacji dla społeczności mniejszościowych, bez uwzględniania społeczności kaszubskiej, wyniosła 101.056.590,60 zł. W tym roku najwyższa kwota dotacji przypadła mniejszości niemieckiej, romskiej, białoruskiej

\footnotetext{
${ }^{39}$ IV Raport dotyczący sytuacji mniejszości narodowych i etnicznych oraz języka regionalnego w Rzeczypospolitej Polskiej-2013 - http://mniejszosci.narodowe.mswia.gov.pl/mne/prawo/ustawa-o-mniejszosciac/raporty-ustawowe/ 7540,IV-Raport-dotyczacy-sytuacji-mniejszosci-narodowych-i-etnicznych-oraz-jezyka-reg.html (1.07.2019).
} 
i ukraińskiej, najniższa zaś mniejszości czeskiej, karaimskiej i ormiańskiej. Z kolei mniejszość rosyjska nie otrzymała żadnej dotacji ${ }^{40}$.

W 2007 roku łączna kwota dotacji celowych i podmiotowych z budżetu państwa na finansowanie społeczności mniejszościowych oraz społeczności posługującej się językiem regionalnym wyniosła 139.343.284,03 zł (z czego subwencja oświatowa wyniosła ogółem 114.599.491 zł - nie podano kwot dotyczących każdej mniejszości z osobna). Kwota dotacji dla społeczności mniejszościowych, bez uwzględniania społeczności kaszubskiej, wyniosła 137.442.661,03 zł. W tym roku największa kwota dotacji przypadła mniejszości romskiej, białoruskiej i ukraińskiej, najniższa zaś mniejszości czeskiej, tatarskiej i rosyjskiej ${ }^{41}$.

W 2008 roku łączna kwota dotacji celowych i podmiotowych na finansowanie społeczności mniejszościowych wyniosła 165.144.212,96 zł (z czego subwencja oświatowa wyniosła 137.732.616 zł - nie podano kwot dotyczących każdej mniejszości z osobna). Kwota dotacji dla społeczności mniejszościowych, bez uwzględniania społeczności kaszubskiej, wyniosła 163.157.318,51 zł. W tym roku największa kwota dotacji przypadła mniejszości romskiej, niemieckiej, łemkowskiej żydowskiej, najniższa zaś mniejszości rosyjskiej i czeskiej ${ }^{42}$.

W 2009 roku łączna kwota dotacji celowych i podmiotowych na finansowanie społeczności mniejszościowych wyniosła 196.105.053,40 zł (z czego subwencja oświatowa wyniosła 170.197.043 zł - największa kwota na rzecz społeczności niemieckiej, romskiej i ukraińskiej). Kwota dotacji dla społeczności mniejszościowych, bez uwzględniania społeczności kaszubskiej, wyniosła 147.286.998,4zł.W tym roku najwyższa dotacja przypadła mniejszości niemieckiej, białoruskiej, litewskiej i łemkowskiej, najniższa zaś mniejszości czeskiej i tatarskiej ${ }^{43}$.

W 2010 roku łączna kwota dotacji celowych i podmiotowych na finansowanie społeczności mniejszościowych wyniosła 222.812.715,31 zł (z czego subwencja oświatowa wyniosła 197.470.927 zł - najwyższa dla mniejszości niemieckiej, romskiej i ukraińskiej). Kwota dotacji dla społeczności mniejszościowych, bez uwzględniania społeczności kaszubskiej, wyniosła 159.080.944,18 zł. W tym roku najwyższa kwota dotacji przypadła mniejszości niemieckiej, romskiej, białoruskiej i łemkowskiej, najniższa zaś mniejszości karaimskiej i tatarskiej, mniejszość czeska natomiast nie otrzymała żadnej dotacji.

W 2011 roku łączna kwota dotacji celowych i podmiotowych na finansowanie społeczności mniejszościowych wyniosła 235.894.060,82 zł (z czego subwencja oświatowa wyniosła 209.493.998,95 zł - najwyższa na rzecz mniejszości niemieckiej, ukraińskiej i białoruskiej). Kwota dotacji dla społeczności mniejszościowych, bez uwzględniania społeczności kaszubskiej,

\footnotetext{
${ }^{40}$ I Raport dotyczący sytuacji mniejszości narodowych i etnicznych oraz języka regionalnego w Rzeczypospolitej Polskiej- 2007, s. 46 - http://mniejszosci.narodowe.mswia.gov.pl/mne/prawo/ustawa-o-mniejszosciac/raportyustawowe/6491,I-Raport-dotyczacy-sytuacji-mniejszosci-narodowych-i-etnicznych-oraz-jezyka-regi.html (1.07.2019).

${ }^{41}$ II Raport dotyczący sytuacji mniejszości narodowych i etnicznych oraz języka regionalnego w Rzeczypospolitej Polskiej-2009, s. 14-16 - http://mniejszosci.narodowe.mswia.gov.pl/mne/prawo/ustawa-o-mniejszosciac/raportyustawowe/6964,II-Raport-dotyczacy-sytuacji-mniejszosci-narodowych-i-etnicznych-oraz-jezyka-reg.html (1.07.2019). ${ }^{42}$ Ibidem.

${ }^{43}$ Ibidem.
} 
wyniosła 159.996.454,87 zł. W tym roku najwyższa kwota dotacji przypadła mniejszości niemieckiej, ukraińskiej, białoruskiej i romskiej, najniższa zaś mniejszości rosyjskiej i czeskiej ${ }^{44}$.

W 2012 roku łączna kwota dotacji celowych i podmiotowych na finansowanie społeczności mniejszościowych wyniosła 297.097.525,64 zł (z czego subwencja oświatowa wyniosła 270.558 .000 zł - najwyższa na rzecz mniejszości niemieckiej, romskiej, ukraińskiej i białoruskiej). Kwota dotacji dla społeczności mniejszościowych, bez uwzględniania społeczności kaszubskiej, wyniosła 196.460.849,68 zł. W tym roku najwyższa kwota dotacji przypadła mniejszości niemieckiej, romskiej, ukraińskiej i białoruskiej, najniższa zaś mniejszości czeskiej karaimskiej i tatarskiej ${ }^{45}$.

W 2013 roku łączna kwota dotacji celowych i podmiotowych na finansowanie społeczności mniejszościowych wyniosła 307.590.367 zł (z czego subwencja oświatowa wyniosła 280.925.792 - najwyższa na rzecz mniejszości niemieckiej, romskiej, białoruskiej i ukraińskiej). Kwota dotacji dla społeczności mniejszościowych, bez uwzględniania społeczności kaszubskiej, wyniosła 199.412.292 zł. W tym roku najwyższa kwota dotacji przypadła mniejszości niemieckiej, romskiej, ukraińskiej i białoruskiej, najniższa zaś mniejszości czeskiej, karaimskiej i tatarskiej ${ }^{46}$.

W 2014 roku łączna kwota dotacji celowych i podmiotowych na finansowanie społeczności mniejszościowych wyniosła 319.089.726,41 zł (z czego subwencja oświatowa wyniosła 296.684.45 zł - najwyższa na rzecz mniejszości niemieckiej, romskiej, ukraińskiej i białoruskiej. Kwota dotacji dla społeczności mniejszościowych, bez uwzględniania społeczności kaszubskiej, wyniosła 200.696.079,11 zł. W tym roku najwyższa kwota dotacji przypadła mniejszości niemieckiej, romskiej, białoruskiej i ukraińskiej, najniższa zaś mniejszości czeskiej, karaimskiej i rosyjskiej $^{47}$.

W 2015 roku łączna kwota dotacji celowych i podmiotowych na finansowanie społeczności mniejszościowych wyniosła 352.834.631,49 zł (z czego subwencja oświatowa wyniosła 326.010.879,49 zł - brak danych odnośnie kwot przyznanych poszczególnym mniejszościom). Kwota dotacji dla społeczności mniejszościowych, bez uwzględniania społeczności kaszubskiej, wyniosła 224.075.039,87 zł. W tym roku najwyższa kwota dotacji przypadła mniejszości niemieckiej, romskiej, ukraińskiej i białoruskiej, najniższa zaś mniejszości czeskiej, karaimskiej i rosyjskiej ${ }^{48}$.

\footnotetext{
${ }^{44}$ III Raport dotyczący sytuacji mniejszości narodowych i etnicznych oraz języka regionalnego w Rzeczypospolitej Polskiej-2011, s. 14-15 - http://mniejszosci.narodowe.mswia.gov.pl/mne/prawo/ustawa-o-mniejszosciac/raportyustawowe/6965,III-Raport-dotyczacy-sytuacji-mniejszosci-narodowych-i-etnicznych-oraz-jezyka-re.html (1.07.2019). ${ }^{45}$ IV Raport dotyczący sytuacji mniejszości narodowych i etnicznych oraz języka regionalnego w Rzeczypospolitej Polskiej-2013, s. 51-52 - http://mniejszosci.narodowe.mswia.gov.pl/mne/prawo/ustawa-o-mniejszosciac/raportyustawowe/7540,IV-Raport-dotyczacy-sytuacji-mniejszosci-narodowych-i-etnicznych-oraz-jezyka-reg.html (1.07.2019).

${ }^{46}$ Ibidem.

${ }^{47}$ V Raport dotyczący sytuacji mniejszości narodowych i etnicznych oraz języka regionalnego w Rzeczypospolitej Polskiej- 2015, s. 52-53 - http://mniejszosci.narodowe.mswia.gov.pl/mne/prawo/ustawa-o-mniejszosciac/raportyustawowe/9711,V-Raport-dotyczacy-sytuacji-mniejszosci-narodowych-i-etnicznych-oraz-jezyka-regi.html (1.07.2019).

${ }^{48}$ Ibidem.
} 
W 2016 roku łączna kwota dotacji celowych i podmiotowych na finansowanie społeczności mniejszościowych wyniosła 372.995.938,38 zł (z czego subwencja oświatowa wyniosła 356784342,88 zł - najwyższa na rzecz mniejszości niemieckiej, ukraińskiej, romskiej i białoruskiej). Kwota dotacji dla społeczności mniejszościowych, bez uwzględniania społeczności kaszubskiej wyniosła 234.501.075,69 zł. W tym roku najwyższa kwota dotacji przypadła mniejszości niemieckiej, ukraińskiej, romskiej i białoruskiej, najniższa zaś mniejszości czeskiej, karaimskiej i tatarskiej ${ }^{49}$.

Sukcesywny wzrost kwot dotacji przeznaczonych dla społeczności mniejszościowych na przestrzeni lat 2006-2016 obrazuje wykres nr 1.

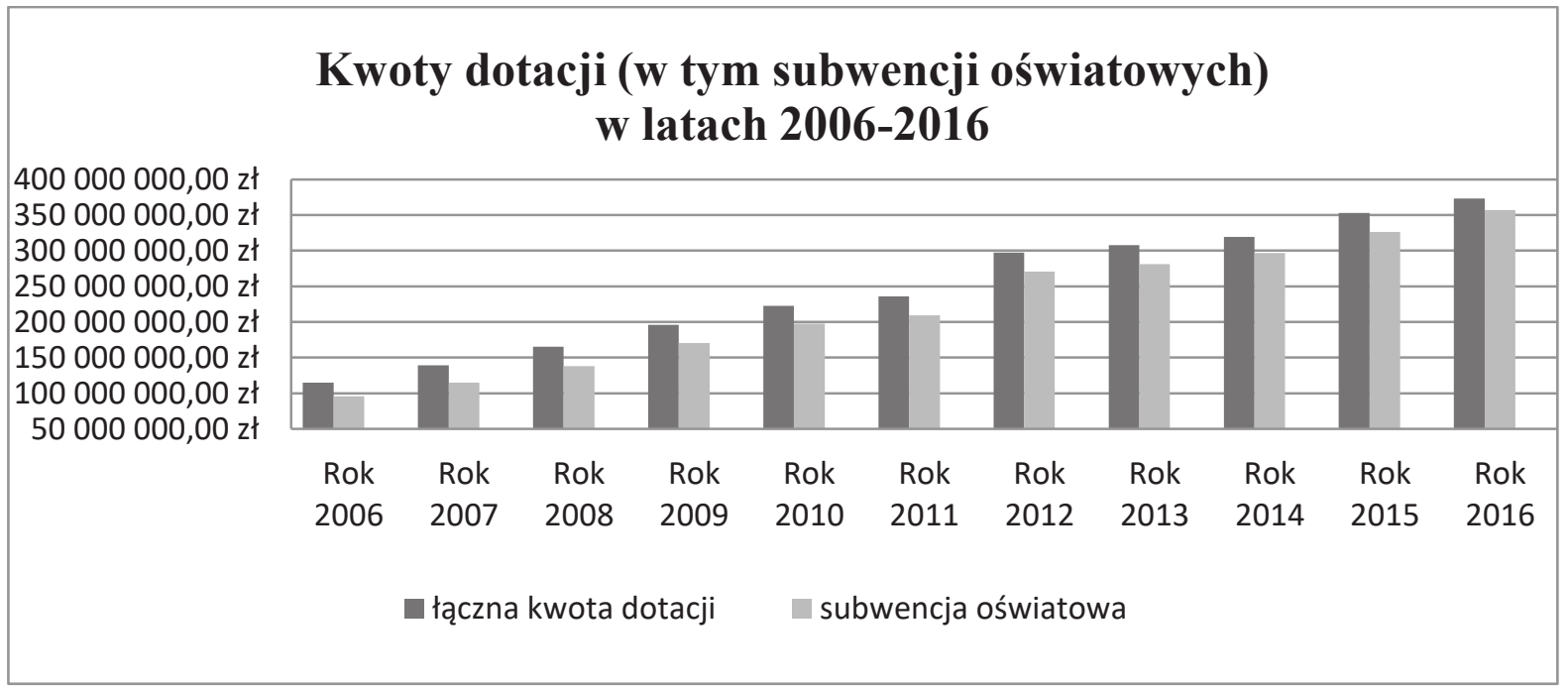

Wykres nr 1: Kwoty dotacji (w tym subwencji oświatowych) w latach 2006-2016 przyznane na rzecz mniejszości narodowych i etnicznych w Polsce oraz społeczności posługującej się językiem regionalnym-kaszubskim.

Źródło: opracowanie własne na podstawie Raportów ustawowych dotyczących sytuacji mniejszości narodowych i etnicznych oraz języka regionalnego w Rzeczypospolitej Polskiej oraz IV Raportu dla Sekretarza Generalnego Rady Europy z realizacji przez Rzeczpospolitą Polską postanowień Konwencji ramowej o ochronie mniejszości narodowych.

Jeżeli chodzi o zestawienie dotacji celowych i podmiotowych w latach 2017-2018 z uwzględnieniem podziału na kwoty przyznane poszczególnym mniejszościom narodowym i etnicznym, to brak jest na chwilę obecną opracowania w postaci raportu ustawowego za te lata. Najprawdopodobniej jednak tendencje w tym zakresie pozostaną podobne. Jeżeli chodzi z kolei o lata 2006-2016, to nie ulega wątpliwości, że nastąpił dość znaczny wzrost kwot wydatkowanych z budżetu państwa na wspieranie działalności zmierzającej do ochrony, zachowania i rozwoju tożsamości kulturowej mniejszości narodowych i etnicznych oraz języka regionalnego. Na przestrzeni 10 lat kwota powyższa zwiększyła się z 114.961.749,60 zł do 372.995.938,38 zł (uwzględniając także dotacje na rzecz społeczności kaszubskiej, posługującej się językiem regionalnym), a więc ponad trzykrotnie. Jeżeli chodzi z kolei o kwoty dotacji

\footnotetext{
${ }^{49}$ IV Raport dla Sekretarza Generalnego Rady Europy z realizacji przez Rzeczpospolitą Polską postanowień Konwencji ramowej o ochronie mniejszości narodowych - http://mniejszosci.narodowe.mswia.gov.pl/ mne/prawo/konwencja-ramowa-rady/raporty-dla-sekretarza/-ivrport/10989,IV-Raport-dla-Sekretarza-GeneralnegoRady-Europy-z-realizacji-przez-Rzeczpospoli.html (1.07.2019).
} 
przeznaczonych na rzecz mniejszości narodowych i etnicznych, z wyłączeniem dotacji przyznanych na rzecz społeczności posługującej się językiem regionalnym, to również widoczny jest wzrost tych kwot, tj. od łącznej kwoty 101.056.590,60 zł w roku 2006, do kwoty 234.501.075,69 zł w roku 2016. Jest to zatem również wzrost ponad dwukrotny, choć nie systematyczny na przestrzeni lat 2006-2016, gdyż w roku 2009 nastąpił spadek wysokości kwoty dotacji, co obrazuje wykres nr 2.

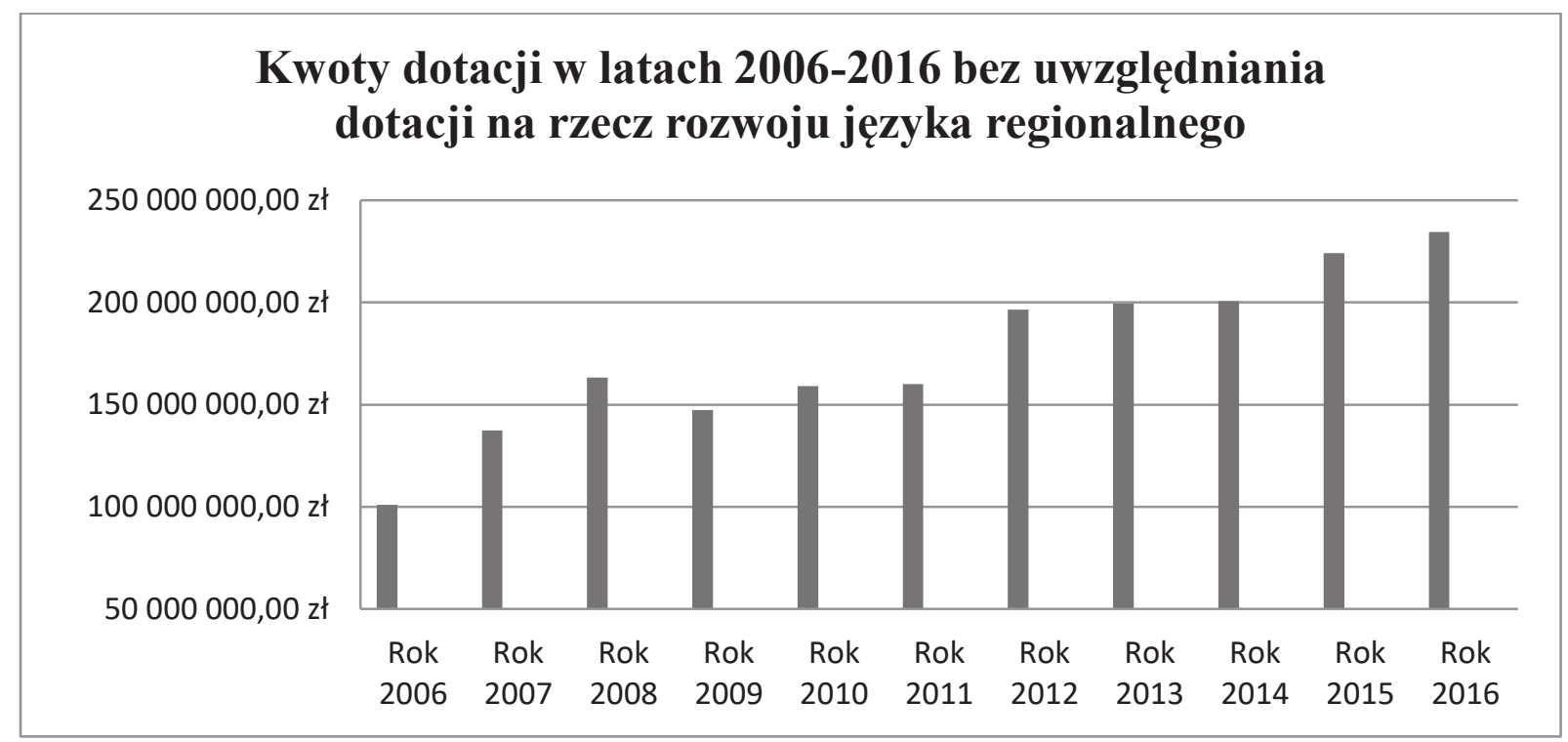

Wykres 2. Kwoty dotacji przyznane w latach 2006-2016 na rzecz mniejszości narodowych i etnicznych w Polsce bez uwzględniania dotacji na rzecz języka regionalnego.

Źródło: opracowanie własne na podstawie Raportów ustawowych dotyczących sytuacji mniejszości narodowych i etnicznych oraz języka regionalnego w Rzeczypospolitej Polskiej oraz IV Raportu dla Sekretarza Generalnego Rady Europy z realizacji przez Rzeczpospolitą Polską postanowień Konwencji ramowej o ochronie mniejszości narodowych.

Z wyżej przedstawionych zestawień za lata 2006-2016 wynika, że w zasadzie finansowanie poszczególnych mniejszości narodowych i etnicznych, mimo systematycznego wzrostu kwot dotacji, wykazuje te same tendencje, tj. najwyższe kwoty dotacji, w tym subwencji oświatowych, otrzymują najliczniejsze mniejszości w Polsce, tj. mniejszość niemiecka (ok. 144238 osób), białoruska (ok. 43880 osób), ukraińska (ok. 38797 osób) oraz romska (ok. 16725 osób), co rzecz jasna wynika z większych potrzeb tak licznych grup społecznych.

Ten stały trend obrazują wykresy nr 3 i 4, w których przedstawiono udział poszczególnych mniejszości narodowych i etnicznych w łącznej kwocie dotacji przyznanych na rzecz społeczności mniejszościowych (bez uwzględniania dotacji przyznanych społeczności posługującej się językiem regionalnym - kaszubskim) w roku 2006 oraz w roku 2016. Z wykresów wynika, że niemalże te same mniejszości w największym stopniu skorzystały z finansowania państwa zarówno w roku 2006, jak i 2016. 


\section{Udział poszczególnych mniejszości narodowych i etnicznych w lącznej kwocie dotacji dla społeczności mniejszościowych przyznanych w roku 2006}

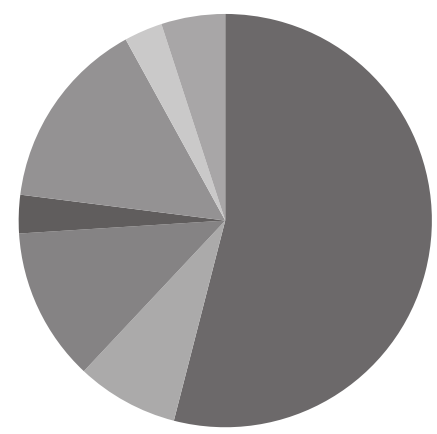

niemiecka białoruska ukraińska - litewska romska żydowska inne mniejszości

Wykres 3. Udział poszczególnych mniejszości narodowych i etnicznych w łącznej kwocie dotacji dla społeczności mniejszościowych przyznanych w roku 2006.

Źródło: opracowanie własne na podstawie Raportów ustawowych dotyczących sytuacji mniejszości narodowych i etnicznych oraz języka regionalnego w Rzeczypospolitej Polskiej.

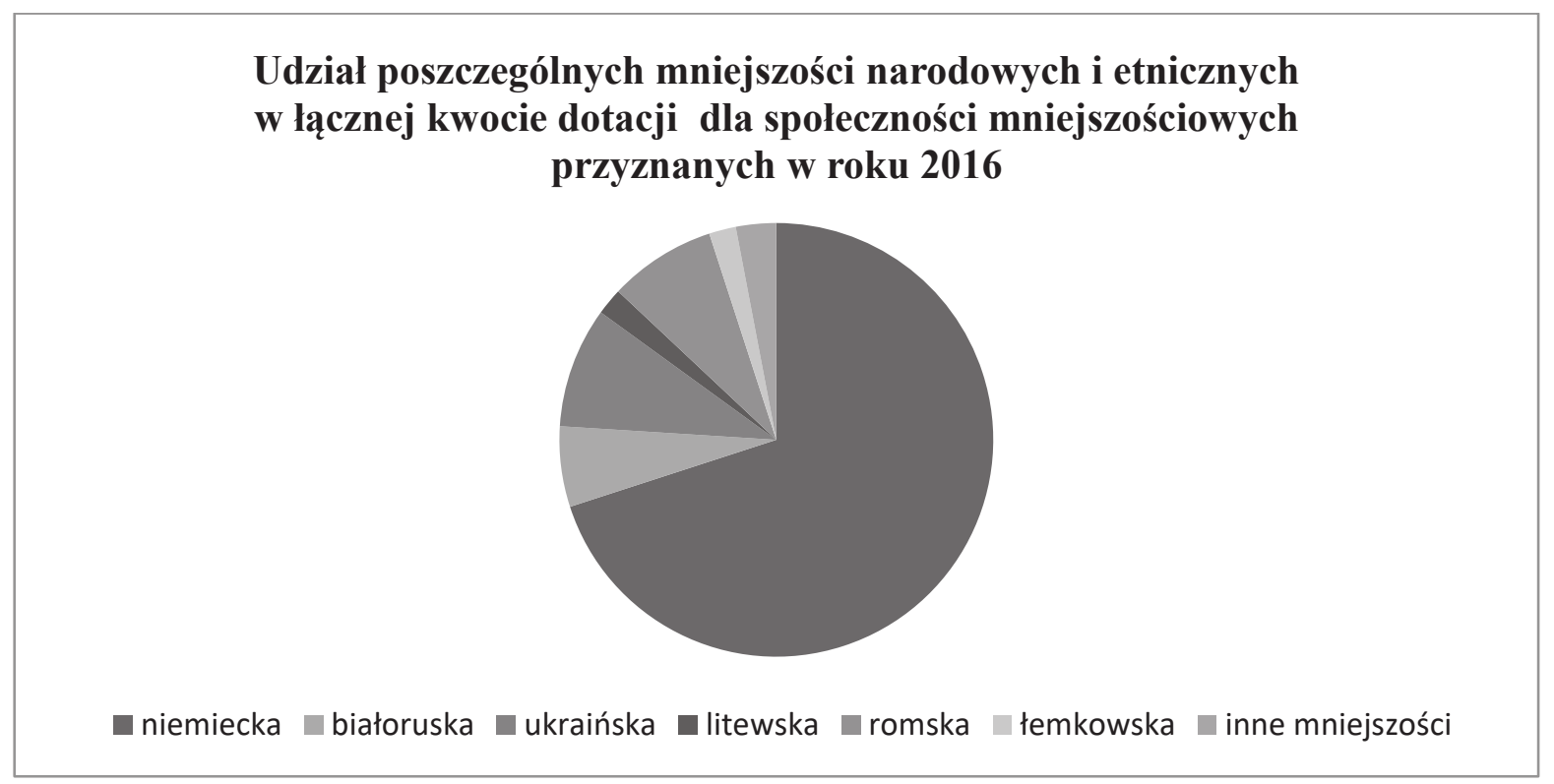

Wykres 4. Udział poszczególnych mniejszości narodowych i etnicznych w łącznej kwocie dotacji dla społeczności mniejszościowych przyznanych w roku 2016.

Źródło: opracowanie własne na podstawie IV Raportu dla Sekretarza Generalnego Rady Europy z realizacji przez Rzeczpospolitą Polską postanowień Konwencji ramowej o ochronie mniejszości narodowych.

Z kolei wśród mniejszości narodowych, na rzecz których przyznawano na przestrzeni tych lat najniższe dotacje znalazła się mniejszość czeska i rosyjska, choć żadna z tych mniejszości nie należy do najmniej licznych mniejszości narodowych (najmniej liczną mniejszością narodową 
jest obecnie mniejszość słowacka licząca ok. 2740 osób) $)^{50}$. Prawdopodobnie wpływ na taki stan rzeczy miała mała aktywność tych społeczności w zakresie składanych wniosków o przyznanie dotacji. Należy zaznaczyć, że różnice pomiędzy najwyższą a najniższą kwotą dotacji są bardzo znaczne, np. w roku 2015 mniejszość niemiecka otrzymała 148.103.687,41 zł dotacji, mniejszość czeska natomiast jednie $87.100 \mathrm{zł}$.

Jak podnosi się w ostatnim Raporcie dotyczącym sytuacji mniejszości narodowych i etnicznych z 2015 roku, dane umieszczone w tabelach nie uwzględniają również kwot przekazywanych przez Ministra Kultury i Dziedzictwa Narodowego na realizację zadań w różnym stopniu służących rozwojowi kultury oraz promocji wiedzy o historii i tradycji mniejszości narodowych i etnicznych oraz zachowaniu i rozwojowi języka regionalnego. Większość zadań realizowanych dzięki wspomnianym dotacjom miała na celu promocję wiedzy o historii, tradycji i kulturze mniejszości. Miały one jednak również znaczenie dla podtrzymania i rozwoju tożsamości kulturowej mniejszości. Z dotacji Ministra Kultury i Dziedzictwa Narodowego w okresie objętym niniejszym raportem skorzystały mniejszości karaimska, łemkowska, romska, ormiańska, ukraińska i żydowska oraz społeczność posługująca się językiem regionalnym. Łączna kwota wydatków przeznaczonych z budżetu wyżej wymienionego organu administracji rządowej na te cele w ramach dotacji dla podmiotów zewnętrznych w latach 2013-2014 wyniosła 10.736.466,47 zł ${ }^{51}$.

Mimo iż wyżej zaprezentowane kwoty wydają się znaczne, nierzadko społeczności mniejszościowe zgłaszają zastrzeżenia co do sposobu ich wydatkowania i rzeczywistego ich przeznaczania na wsparcie dla społeczności mniejszościowych. Chodzi w szczególności o sytuację, kiedy poszczególne kwoty z budżetu państwa określone jako dotacje dla społeczności mniejszościowych są przekazywane samorządom terytorialnym lub konkretnym placówkom (np. szkołom), w którym prowadzone jest nauczanie języka lub w języku mniejszości. Jak podnoszą środowiska mniejszościowe, zdarza się, że takie środki przekazywane z budżetu państwa nie są $\mathrm{w}$ dalszej kolejności rozdysponowane na zaspokajanie potrzeb społeczności mniejszościowych. Tego typu zarzuty pojawiały się na etapie opracowywania w zasadzie każdego raportu ustawowego dotyczącego sytuacji mniejszości narodowych i etnicznych na przestrzeni lat 2005-2015. Wydaje się, że rozwiązanie takiego problemu w zakresie ostatecznego właściwego zadysponowania dotacji przekazanych do budżetu samorządu terytorialnego powinno odbyć się na szczeblu właściwych zmian normatywnych.

Należy również wspomnieć o szczególnej sytuacji społeczności romskiej, która jest najbardziej narażona na zjawisko ewentualnego wykluczenia społecznego. Romowie pozostają w najtrudniejszym położeniu społeczno-ekonomicznym, znacząco odróżniającym się na tle pozostałych mniejszości narodowych i etnicznych. Z tego względu w latach 2004-2013 na terenie całego kraju realizowany był „Program na rzecz społeczności romskiej w Polsce”, przyjęty przez

\footnotetext{
50 http://mniejszosci.narodowe.mswia.gov.pl/mne/mniejszosci/charakterystyka-mniejs/6480, Charakterystykamniejszosci-narodowych-i-etnicznych-w-Polsce.html (1.07.2019).

${ }^{51} \mathrm{~V}$ Raport dotyczący sytuacji...,op. cit.
} 
Radę Ministrów 19 sierpnia 2003 roku, będący kontynuacją wcześniejszego, regionalnego trzyletniego pilotażu. Działania podejmowane w „Programie na rzecz społeczności romskiej w Polsce” są kontynuowane w „Programie integracji społeczności romskiej w Polsce na lata 2014-2020", przyjętym przez Radę Ministrów w dniu 7 października 2014 roku. Należy również wskazać na programy stypendialne dla młodzieży romskiej, które co roku ogłaszane są przez ministra właściwego do spraw wyznań religijnych oraz mniejszości narodowych i etnicznych ${ }^{52}$.

Rozważania w zakresie efektywności systemu bezpieczeństwa mniejszości nie mogą obyć się także bez odniesienia do kwestii edukacji języka lub w języku mniejszości. To jedno z ważniejszych uprawnień, którego właściwa realizacja gwarantuje możliwość zachowania narodowej bądź etnicznej tożsamości przez najmłodsze pokolenia.

Jak wywnioskować można $\mathrm{z}$ raportów dotyczących sytuacji mniejszości narodowych i etnicznych w okresie obowiązywania ustawy z dnia 6 stycznia 2005 roku, liczba placówek prowadzących tego typu nauczenie oraz ich uczniów zwiększyła się. Należy jednak pamiętać, że ogólne zestawienia w tym zakresie i przedstawione przez MSWiA wyniki uwzględniają również placówki z nauką języka lub w języku regionalnym, tj. kaszubskim. W poniższym zestawieniu język regionalny, pozostający poza zakresem niniejszego opracowania, nie zostanie uwzględniony.

W roku szkolnym 2005/2006 odnotowano łącznie 621 placówek (szkół podstawowych, gimnazjalnych i ponadgimnazjalnych) z nauczaniem języka mniejszości lub w języku mniejszości ${ }^{53}$. Najwyższy odsetek stanowiły szkoły podstawowe z dodatkową nauką języka niemieckiego (350 placówek), najniższy zaś placówki z nauką języka lub w języku mniejszości ormiańskiej i żydowskiej (2 placówki). Odnotowano również szkoły, w których nauczano języka lub w języku mniejszości białoruskiej, litewskiej, słowackiej, ukraińskiej, łemkowskiej i słowackiej, a łączna liczba uczniów tych placówek wniosła 43097.

W roku szkolnym 2008/2009 liczba tego typu szkół zwiększyła się do liczby 645 i również zdecydowanie dominowały szkoły podstawowe $\mathrm{z}$ możliwością nauki języka lub w języku mniejszości niemieckiej (364 placówki), najmniej liczne były placówki z możliwością nauki języka lub w języku mniejszości ormiańskiej (2 placówki). Wykazano również placówki z nauką języka lub w języku mniejszości białoruskiej, litewskiej, słowackiej, ukraińskiej, łemkowskiej, żydowskiej oraz w języku kaszubskim (regionalnym) ${ }^{54}$. Łączna liczba uczniów tego typu placówek wniosła40255.

W roku szkolnym 2010/2011 liczba szkół z nauką języka lub w języku mniejszości wyniosła 858. Największą część stanowiły szkoły podstawowe z nauką języka mniejszości niemieckiej (558 placówek), najmniejszą zaś z nauką języka ormiańskiego. Nie zmieniła się natomiast liczba mniejszości, które z tego typu uprawnień skorzystały (tj. mniejszość niemiecka,

\footnotetext{
${ }^{52} \mathrm{http}: / /$ mniejszosci.narodowe.mswia.gov.pl/mne/romowie/programy-stypendialne-d (2.07.2019).

${ }^{53}$ I Raport dotyczący sytuacji.., s. 81-82 - http://mniejszosci.narodowe.mswia.gov.pl/mne/prawo/ustawa-omniejszosciac/raporty-ustawowe/6491,I-Raport-dotyczacy-sytuacji-mniejszosci-narodowych-i-etnicznych-orazjezyka-regi.html (2.07.2019).

54 II Raport dotyczący sytuacji.., s. 38 - http://mniejszosci.narodowe.mswia.gov.pl/mne/prawo/ustawa-omniejszosciac/raporty-ustawowe/6964,II-Raport-dotyczacy-sytuacji-mniejszosci-narodowych-i-etnicznych-orazjezyka-reg.html (2.07.2019).
} 
białoruska, ukraińska, litewska, słowacka, łemkowska, ormiańska, żydowska) Łączna liczba uczniów tego typu placówek wniosła43572 $2^{55}$.

W roku szkolnym 2012/2013 liczba placówek z nauczaniem języka lub w języku mniejszości wyniosła 639, a więc nastąpił dość znaczny spadek w porównaniu z danymi z 2011 roku. Nadal nauczano natomiast języka lub w języku mniejszości niemieckiej (najwięcej, bo 406 placówek), białoruskiej, ukraińskiej, litewskiej, słowackiej, łemkowskiej, ormiańskiej (najmniejsza liczba - 3 placówki) i żydowskiej oraz w języku regionalnym, a liczba uczniów korzystających $\mathrm{z}$ tego uprawnienia wyniosła $38631^{56}$.

W roku szkolnym 2014/2015 liczba wyżej określonych placówek wyniosła 750, liczba uczniów zaś korzystających z prawa do nauki języka lub w języku mniejszości - 44849. Nauczano języka lub w języku mniejszości niemieckiej (najwięcej, bo 506 placówek), białoruskiej, ukraińskiej, litewskiej, łemkowskiej, ormiańskiej (najmniejsza liczba placówek - 4), żydowskiej i słowackiej ${ }^{57}$.

Z powyższych danych wynika, że na przestrzeni lat 2005-2015 liczba uczniów korzystających z możliwości nauki języka lub w języku mniejszości zwiększyła się o ponad 1752, choć nie był to stały wzrost. Wzrosła również liczba szkół, które oferują tego typu możliwości, aczkolwiek również nie jest to stały wzrost na przestrzeni lat 2006-2015, co obrazuje wykres nr 5. Należy mieć nadzieję, że mniejszości narodowe i etniczne w przyszłych latach będą efektywniej korzystać z możliwości nauki swojego języka.

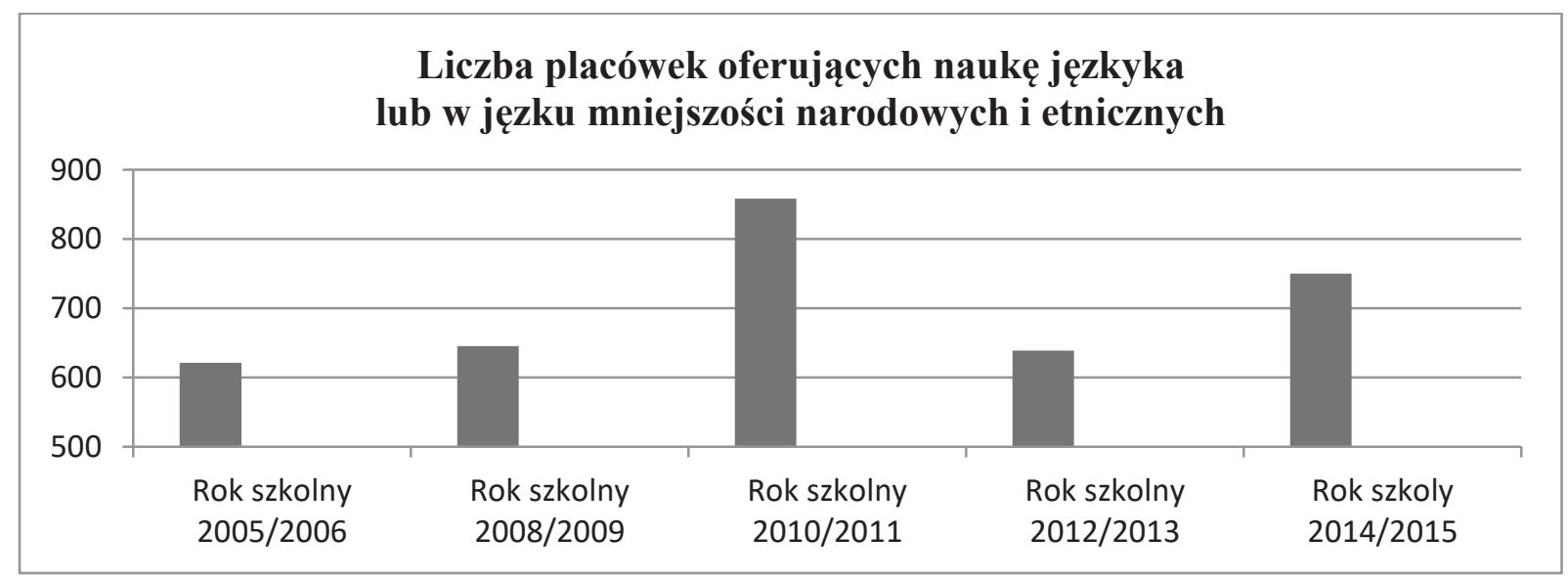

Wykres nr 5: Liczba szkół (podstawowych, gimnazjalnych i ponadgimnazjalnych) oferujących naukę języka lub w języku mniejszości narodowych i etnicznych.

Źródło: opracowanie własne na podstawie Raportów ustawowych dotyczących sytuacji mniejszości narodowych i etnicznych oraz języka regionalnego w Rzeczypospolitej Polskiej.

\footnotetext{
55 III Raport dotyczący sytuacji.., s. 36 - http://mniejszosci.narodowe.mswia.gov.pl/mne/prawo/ustawa-omniejszosciac/raporty-ustawowe/6965,III-Raport-dotyczacy-sytuacji-mniejszosci-narodowych-i-etnicznych-orazjezyka-re.html (2.07.2019).

56 IV Raport dotyczący sytuacji.., s. 102 - http://mniejszosci.narodowe.mswia.gov.pl/mne/prawo/ustawa-omniejszosciac/raporty-ustawowe/7540,IV-Raport-dotyczacy-sytuacji-mniejszosci-narodowych-i-etnicznych-orazjezyka-reg.html (2.07.2019).

${ }_{57} \mathrm{~V}$ Raport dotyczący sytuacji.., s. 117 - http://mniejszosci.narodowe.mswia.gov.pl/mne/prawo/ustawa-omniejszosciac/raporty-ustawowe/9711,V-Raport-dotyczacy-sytuacji-mniejszosci-narodowych-i-etnicznych-orazjezyka-regi.html (2.07.2019).
} 
Niepokoić może natomiast niezmieniające się na przestrzeni lat pozbawienie takiej możliwości kilku, tych samych społeczności mniejszościowych, tj. mniejszości czeskiej, rosyjskiej, tatarskiej, karaimskiej i romskiej, choć jeśli chodzi o tę ostatnią, jest to podyktowane specyficzną tradycją romska, w której nauczanie języka romani nie może odbywać się poza ścisłym kręgiem tej społeczności. W grupach ortodoksyjnych (a takich Romów żyje w Polsce najwięcej) język oddziela symbolicznie od niecygańskiego świata, więc wprowadzenie go do szkół czy umożliwienie jego nauki nie-Cyganom byłoby czynem wysoce nagannym i zasługującym na potępienie $^{58}$. Z kolei język karaimski w zasadzie jest językiem wymarłym na terenie Polski. Jeżeli zaś chodzi o język tatarski, to według doniesień mniejszości tatarskiej (niezweryfikowanych nadal na gruncie kolejnego raportu ustawowego o sytuacji mniejszości) dążono od 2016 roku do wznowienia jego nauki w placówkach oświatowych ${ }^{59}$. Odnosząc się z kolei do braku placówek, w których istniałaby możliwość nauczania języka lub w języku mniejszości czeskiej czy rosyjskiej, to przypuszczać można, że taki stan rzeczy spowodowany jest brakiem stosownego wniosku rodziców uczniów, którzy byliby zainteresowani realizacją tego uprawnienia.

\section{Podsumowanie}

Analiza dostępnej literatury przedmiotu, obowiązujących aktów normatywnych oraz danych statystycznych pozwala wysnuć wniosek, że kierunek polityki bezpieczeństwa państwa w zakresie mniejszości narodowych i etnicznych w Polsce jest co do zasady właściwy. Bezpieczeństwo mniejszości narodowych i etnicznych, jako kategoria oscylująca na pograniczu bezpieczeństwa społecznego i kulturowego, to z pewnością warunek zachowania ładu i spokoju w państwie, a w szerszej perspektywie to determinanta bezpieczeństwa w skali międzynarodowej.

Ramy systemu mniejszości narodowych i etnicznych w Polsce w zakresie normatywnym i instytucjonalnym w zasadzie nie budzą większych wątpliwości. Przełomem w kwestii kształtowania się polityki bezpieczeństwa mniejszości było uchwalenie ustawy o mniejszościach narodowych i etnicznych oraz o języku regionalnym z dnia 6 stycznia 2005 roku, wychodzącej naprzeciw wielu oczekiwaniom środowisk mniejszościowych, na gruncie której określono po raz pierwszy legalną definicje mniejszości narodowych i etnicznych w Polsce, unormowano zasady realizacji uprawnień językowych przede wszystkim w sferze życia publicznego oraz zawarto rozwiązania w zakresie zasad finansowego wsparcia społeczności mniejszościowych, umożliwiającego podtrzymywanie ich kultury, tradycji i języka.

Pewne zastrzeżenia ze strony środowisk mniejszościowych, jeżeli chodzi o normatywne ramy systemu bezpieczeństwa mniejszości, budzi dodanie do wyżej wymienionej ustawy zapisu o integracji społecznej mniejszości, która kojarzona jest z przymusową asymilacją mniejszości, stanowiącą przecież jedno z poważniejszych zagrożeń tego systemu. Na chwilę

\footnotetext{
${ }^{58}$ J. Cukras-Stelągowska, J. Szelągowski, W kierunku edukacji międzykulturowej. Parafialna szkoła romska w Suwałkach, „Edukacja i Kultura 2009”, nr 1 (70), Torun 2009, s. 116.

${ }^{59} \mathrm{http}: / /$ ztrp.pl/tag/jezyk-tatarski/ (2.07.2019).
} 
obecną nie można jednak wykazać, by w istocie tego rodzaju działania były ze stron władz państwowych podejmowane.

Uzasadnione zastrzeżenia społeczności mniejszościowych budzą także unormowania uzależniające możliwość realizacji uprawnień językowych (stosowanie języka mniejszości jako języka pomocniczego oraz używanie dwujęzycznych nazw miejscowości i ulic) od liczebności danej społeczności (liczba mieszkańców gminy należących do mniejszości, której język ma być używany jako język pomocniczy lub w której języku będą stosowane nazwy miejscowości i ulic, nie może być mniejsza niż 20\% ogólnej liczby mieszkańców gminy). Taki próg ustawowy jest często nie do osiągnięcia dla wielu środowisk mniejszościowych i z góry wyklucza możliwość korzystania z tych uprawnień językowych przez wiele mniej licznych mniejszości narodowych i etnicznych, co zresztą potwierdzają dane zaprezentowane na gruncie niniejszej publikacji. Tego typu rozwiązania normatywne z pewnością wymagają rewizji.

Analiza danych z ostatnich lat dotyczących finansowego wsparcia mniejszości narodowych i etnicznych w Polsce ze środków pochodzących z budżetu państwa, jak również dostępu dzieci i młodzieży ze środowisk mniejszościowych do nauki języka lub w języku mniejszości, wykazała wzrost w tym zakresie. Oczywistym jest natomiast, że największe profity przypadają najliczniejszym mniejszościom (przede wszystkim chodzi o mniejszość niemiecką, białoruską, ukraińską i romską). Duża liczba osób zainteresowanych korzystaniem z tego rodzaju uprawnień przekłada się zatem na efektywniejszą pomoc w realizacji danych potrzeb. Problemem występującym jednak na tej płaszczyźnie, akcentowanym przez środowiska mniejszościowe, jest brak przejrzystości w zasadach rozdysponowania środków pieniężnych (także subwencji oświatowych) przeznaczonych jako dotacje dla mniejszości, które z budżetu państwa trafiają do budżetów poszczególnych jednostek samorządu terytorialnego. Nie ulega wątpliwości, że tego typu uchybienia $\mathrm{w}$ zakresie efektywności systemu bezpieczeństwa państwa również wymagają zmian na gruncie normatywnym.

Reasumując, system bezpieczeństwa mniejszości narodowych i etnicznych w Polsce w swoich założeniach i konstrukcji co do zasady nie budzi większych zastrzeżeń. $Z$ pewnością wpisuje się w standardy międzynarodowe w tym zakresie, a nierzadko przewyższa swoim poziomem rozwiązania przyjęte przez inne kraje europejskie. Efektywność zarządzania tą sferą bezpieczeństwa państwa na chwilę obecną także wydaje się satysfakcjonująca, choć w dyskursie publicznym pojawiają się zarzuty ze strony zainteresowanych środowisk, przede wszystkim dotyczące kwestii uchybień o charakterze normatywnym. Są one jednak nieodłączną i pożądaną częścią dyskusji, jaka toczy się stale pomiędzy społecznościami mniejszościowymi a aparatem państwowym. Ważne, by głosy obu stron były dostrzeżone i uwzględnione w kształtowaniu dalszej polityki bezpieczeństwa mniejszości. 


\section{BIBLIOGRAFIA}

Białas Andrzej. 2007. Bezpieczeństwo informacji i usług w nowoczesnej instytucji i firmie. Warszawa: Wydawnictwa Naukowo-Techniczne.

Campion Magdalena, Pabis Katarzyna. Bezpieczeństwo kulturowe mniejszości narodowych i etnicznych w Polsce. Wybrane problemy na przykładzie mniejszości karaimskiej, 230-241. https://www.google.com/url?sa=t\&rct=j\&q=\&esrc=s\&source=web\&cd=2\&cad=rja\&uact= 8\&ved=2ahUKEwiF6o6T4JHjAhWvlIsKHR-

7Cn4QFjABegQIAhAC\&url=http\%3A\%2F\%2Frep.up.krakow.pl\%2Fxmlui\%2Fbitstream $\% 2 F h a n d l e \% 2 F 11716 \% 2 F 673 \% 2 F 0056$ 20150617_ra_bezpieczenstwo_kulturowe_mniejs zosci_k_pabis.pdf\%3Fsequence\%3D1\%26isAllowed\%3Dy\&usg=AOvVaw3TJTx5852vip NkyVgstM-x.

Cukras-Stelągowska Joanna, Szelągowski Jakub.2009. „W kierunku edukacji międzykulturowej. Parafialna szkoła romska w Suwałkach”. Edukacja i Kultura 2009 1(70) : 111-127.

Czaja Jan.2008. Kulturowe czynniki bezpieczeństwa. Kraków: Krakowska Szkoła Wyższa im. Andrzeja Frycza Modrzewskiego.

Czaputowicz Jacek.2012. Bezpieczeństwo międzynarodowe- współczesne koncepcje.Warszawa: Wydawnictwo Naukowe PWN.

Jagiełło-Szostak Anna, Sienko Natalia, Szyszlak Tomasz. 2018. Konflikty kulturowe a bezpieczeństwo. Mniejszości etniczne-ludy tubylcze-uchodźcy w przestrzeni postkomunistycznej. Wrocław. Wydawnictwo Uniwersytetu Wrocławskiego.

Janusz Grzegorz. 2011. Ochrona praw mniejszości narodowych w Europie. Lublin: Wydawnictwo Uniwersytetu Marii Curie-Skłodowskiej.

Kurzępa Elżbieta. 2018. Prawna ochrona języka jako aspekt bezpieczeństwa kulturowego [w:] Maciej Getling, Ireneusz Wojaczek (red.), Człowiek-społeczeństwobezpieczeństwo. Wybrane aspekty. Przemyśl: Wydawnictwo Państwowej Wyższej Szkoły Wschodnioeuropejskiej, 188-215.

Leszczyński Marek. 2011. Bezpieczeństwo społeczne Polaków wobec wyzwań XXI wieku. Warszawa. Wydawnictwo Difin.

Łodziński Sławomir, Warmińska Katarzyna, Gudaszewski Grzegorz. 2015. Mniejszości narodowe i etniczne w Polsce w świetle Narodowego Spisu Powszechnego Ludności 2011 roku. Warszawa: Wydawnictwo Naukowe Scholar.

Maksimiec Stanisław. 2012. Mniejszości narodowe i etniczne w krajach Europy Środkowej i Wschodniej po przystąpieniu do Unii Europejskiej. Warszawa: Wydawnictwo Akademii Obrony Narodowej.

Misiuk Andrzej. 2008. Administracja porządku i bezpieczeństwa publicznego. Zagadnienia prawno-ustrojowe. Warszawa: Wydawnictwa Akademickie i Profesjonalne.

Mniejszości narodowe i etniczne oraz społeczność posługująca się językiem kaszubskim - liczebność (również wg województw)http://mniejszosci.narodowe.mswia.gov.pl/mne/ mniejszosci/wyniki-narodowego-spis/6999,Mniejszosci-narodowe-i-etniczne-orazspolecznosc-poslugujaca-sie-jezykiem-kaszub.html.

Safjan Marek. Pozycja mniejszości w Polsce w świetle orzecznictwa Trybunału Konstytucyjnego. https:/www.google.com/url?sa=t\&rct=j\&q=\&esrc=s\&source=web\&cd=1\&cad=rja\&uact= 8\&ved=2ahUKEwirnbGB4oLjAhVJposKHcL9DKsQFjAAegQIARAC\&url=https $\% 3 \mathrm{~A} \% 2$ 
F\%2Ftrybunal.gov.pl\%2Ffileadmin \%2Fcontent\%2Fdokumenty\%2Fwystapienia\%2F1998_ 2006\%2F20031003.pdf\&usg=AOvVaw3Z8w5x3I-U2Fmm6JdKCbFp.

Skrabacz Aleksandra. 2012. Uwarunkowania tworzenia bezpieczeństwa społecznego w XXI wieku [w:] Skrabacz Aleksandra, Sulowski Stanisław (red.), Bezpieczeństwo społeczne. Pojęcia-Uwarunkowania-Wyzwania. Warszawa. ELIPSA Dom Wydawniczy i Handlowy.

Stańczyk Jerzy. 1996. Współczesne pojmowanie bezpieczeństwa. Warszawa: Instytut Studiów Politycznych PAN.

Struktura narodowo-etniczna, językowa i wyznaniowa ludności Polski. Narodowy Spis Powszechny Ludności i Mieszkań 2011. 2015. Warszawa:Główny Urząd Statystyczny.

Turczyński Paweł. 2011. Bezpieczeństwo europejskie. Systemy, instytucje, funkcjonowanie. Wrocław: Wrocławskie Wydawnictwo Naukowe ATLA2.

I Raport dotyczący sytuacji mniejszości narodowych i etnicznych oraz języka regionalnego w Rzeczypospolitej Polskiej - 2007.

http://mniejszosci.narodowe.mswia.gov.pl/mne/prawo/ustawa-o-mniejszosciac/raportyustawowe/6491,I-Raport-dotyczacy-sytuacji-mniejszosci-narodowych-i-etnicznychoraz-jezyka-regi.html.

II Raport dotyczący sytuacji mniejszości narodowych i etnicznych oraz języka regionalnego w Rzeczypospolitej Polskiej - 2009.

http://mniejszosci.narodowe.mswia.gov.pl/mne/prawo/ustawa-o-mniejszosciac/raportyustawowe/6964,II-Raport-dotyczacy-sytuacji-mniejszosci-narodowych-i-etnicznychoraz-jezyka-reg.html.

III Raport dotyczący sytuacji mniejszości narodowych i etnicznych oraz języka regionalnego w Rzeczypospolitej Polskiej - 2011.

http://mniejszosci.narodowe.mswia.gov.pl/mne/prawo/ustawa-o-mniejszosciac/raportyustawowe/6965,III-Raport-dotyczacy-sytuacji-mniejszosci-narodowych-i-etnicznychoraz-jezyka-re.html.

IV Raport dotyczący sytuacji mniejszości narodowych i etnicznych oraz języka regionalnego w Rzeczypospolitej Polskiej - 2013. http://mniejszosci.narodowe.mswia.gov.pl/mne/ prawo/ustawa-o-mniejszosciac/raporty-ustawowe/7540,IV-Raport-dotyczacy-sytuacjimniejszosci-narodowych-i-etnicznych-oraz-jezyka-reg.html.

V Raport dotyczący sytuacji mniejszości narodowych i etnicznych oraz języka regionalnego w Rzeczypospolitej Polskiej - 2015.

http://mniejszosci.narodowe.mswia.gov.pl/mne/prawo/ustawa-o-mniejszosciac/raportyustawowe/9711,V-Raport-dotyczacy-sytuacji-mniejszosci-narodowych-i-etnicznychoraz-jezyka-regi.html.

IV Raport dla Sekretarza Generalnego Rady Europy z realizacji przez Rzeczpospolitą Polską postanowień Konwencji ramowej o ochronie mniejszości narodowych. http://mniejszosci.narodowe.mswia.gov.pl/mne/prawo/konwencja-ramowarady/raporty-dla-sekretarza/-ivrport/10989,IV-Raport-dla-Sekretarza-GeneralnegoRady-Europy-z-realizacji-przez-Rzeczpospoli.html.

ZaborowskiJ. 1977. Prawne środki zapewnienia bezpieczeństwa i porządku publicznego. Warszawa: Departament Szkolenia i Doskonalenia Zawodowego MSW. 


\section{AKTY PRAWNE}

Konstytucja Rzeczypospolitej Polskiej z dnia 2 kwietnia 1997 roku (Dz. U. z 1997 roku, Nr 78, poz. 483 z późn. zm.

Ustawa z dnia 7 kwietnia 1989 roku Prawo o stowarzyszeniach (Dz. U. z 2019 roku, poz. 713).

Ustawa z dnia 7 września 1991 roku o systemie oświaty (Dz. U. z 2018 roku, poz. 1457 z późn. $\mathrm{zm}$.).

Ustawa z dnia 29 grudnia 1992 roku o radiofonii i telewizji (Dz. U z 209 roku, poz. 361.).

Ustawa z dnia 6 stycznia 2005 o mniejszościach narodowych i etnicznych oraz o języku regionalnym (Dz. U. z 2017 roku, poz. 823 z późn. zm.)

Ustawa z dnia 30 maja 2014 roku o zmianie ustawy o mniejszościach narodowych i etnicznych oraz o języku regionalnym oraz ustawy o działach administracji rządowej (Dz. U. z 2014 roku, poz. 829).

Europejska Konwencja o Ochronie Praw Człowieka i Podstawowych Wolności z dnia 4 listopada 1950 roku (Dz. U. z 1993 roku, Nr 63, poz. 285).

Międzynarodowa Konwencja w sprawie likwidacji wszelkich form dyskryminacji rasowej z dnia 7 marca 1966 roku (Dz. U. z 1969 roku, Nr 25, poz. 187).

Międzynarodowy Pakt Praw Obywatelskich i Politycznych z dnia 19 grudnia 1966 roku (Dz. U. z 1977, poz. 38, poz. 167).

Europejska Karta Języków Regionalnych lub Mniejszościowych z dnia 5 listopada 1992 roku (Dz. U. z 2009 roku, Nr 137, poz. 1121).

Konwencja ramowa o ochronie mniejszości narodowych z dnia 1 lutego 1995 roku (Dz. U. z 2002 roku, $\mathrm{Nr} 22$, poz. 209).

\section{STRONY INTERNETOWE}

https://www.gov.pl/web/mswia

http://mniejszosci.narodowe.mswia.gov.pl/mne/mniejszosci/podmioty-

odpowiedzialn/pelnomocnicy-wojewodow/6488, Osoby-odpowiedzialne-za-sprawy-

mniejszosci-narodowych-i-etnicznych-w-wojewodztwa.html

http://mniejszosci.narodowe.mswia.gov.pl/mne/rejestry/urzedowy-rejestr-

gmin/6884,Urzedowy-Rejestr-Gmin-w-ktorych-jest-uzywany-jezyk-pomocniczy.html

http://mniejszosci.narodowe.mswia.gov.pl/mne/rejestry/rejestr-gmin/6794,Rejestr-gmin-na-

ktorych-obszarze-sa-uzywane-nazwy-w-jezyku-mniejszosci.html

http://mniejszosci.narodowe.mswia.gov.pl/mne/rejestry/urzedowy-rejestr-

gmin/6884,Urzedowy-Rejestr-Gmin-w-ktorych-jest-uzywany-jezyk-pomocniczy.html

http://mniejszosci.narodowe.mswia.gov.pl/mne/mniejszosci/charakterystyka-

mniejs/6480,Charakterystyka-mniejszosci-narodowych-i-etnicznych-w-Polsce.html

http://mniejszosci.narodowe.mswia.gov.pl/mne/romowie/programy-stypendialne-d

http://ztrp.pl/tag/jezyk-tatarski/ 